\title{
Regulating Methylation at H3K27: A Trick or Treat for Cancer Cell Plasticity
}

\author{
Provas Das ${ }^{(1)}$ and Joseph H. Taube *(1) \\ Department of Biology, Baylor University, Waco, TX 76706, USA; Provas_Das@baylor.edu \\ * Correspondence: Joseph_Taube@baylor.edu
}

Received: 29 August 2020; Accepted: 23 September 2020; Published: 29 September 2020

check for updates

Simple Summary: Regulation of gene expression is important for appropriate cell development but can also lead to inappropriate cell transformation resulting in cancer. Modification to the proteins that wrap DNA is essential for regulating gene expression. Mutations in the enzymes that modify such proteins are being discovered in many cancers. This review will cover present knowledge of these enzymes as they relate to cancer initiation and progression.

\begin{abstract}
Properly timed addition and removal of histone 3 lysine 27 tri-methylation (H3K27me3) is critical for enabling proper differentiation throughout all stages of development and, likewise, can guide carcinoma cells into altered differentiation states which correspond to poor prognoses and treatment evasion. In early embryonic stages, H3K27me3 is invoked to silence genes and restrict cell fate. Not surprisingly, mutation or altered functionality in the enzymes that regulate this pathway results in aberrant methylation or demethylation that can lead to malignancy. Likewise, changes in expression or activity of these enzymes impact cellular plasticity, metastasis, and treatment evasion. This review focuses on current knowledge regarding methylation and de-methylation of H3K27 in cancer initiation and cancer cell plasticity.
\end{abstract}

Keywords: H3K27me3; EZH2; KDM6A; KDM6B; cancer cell plasticity

\section{Introduction}

Regulation of gene expression depends on access to the genome and recruitment of trans-acting factors, both of which are processes that are impacted by the histone modification state. Modification of specific histones can be pathologically altered by aberrant "writers" that add modifications, "erasers" that remove modifications, or by the mutation of the histone structure which can prevent the residues from being modified [1,2]. Along with these modifications, alteration in the "readers" can alter the functional outcome of the modification. Tri-methylation of the 27th lysine residue on histone $\mathrm{H3}$ (H3K27me3), while just one of many such modifications, plays an important role in developmentally driven gene silencing and in cancer initiation and progression. This review will cover present knowledge on the role of H3K27me3 and the enzymes which modify this residue in cancer, with a particular focus on cellular plasticity.

\section{Histone Methylation and Demethylation: An Historical Perspective}

Although largely thought of as a genetic disease, current evidence establishes that epigenetic aberrations can play profound and ubiquitous roles in cancer origin and progression [3-5]. Results from large-scale cancer genome sequencing projects describe that an unanticipated $50 \%$ of human cancers harbor mutations in chromatin-related proteins [6,7]. Overwhelming evidence supports the notion that specific genetic, environmental, and metabolic stimuli can disrupt the homeostatic balance in chromatin machinery, which can cause either aberrantly restrictive or permissive responses. Such stimuli can 
act on quiescent or premalignant cells to promote malignancy and/or tumor cells to hasten their progression and adaptation. The ubiquity of such stimuli means that epigenetic defects are involved in various aspects of cancer [8-10].

Histone modifications, DNA methylation, chromatin architecture, and the expression of non-coding transcripts drive the epigenetic state of a cell. The N-terminal tails of histones can undergo a variety of post-translational covalent modifications which can then impact critical DNA-dependent processes like replication, transcription, and repair [11,12]. Histone methylation is mediated by methyltransferases that catalyze the mono-, di-, or tri- methylation of specific residues. Dynamic and reversible methylation of histones plays an important role in the regulation of gene expression. Two major families of histone methyltransferases are lysine methyltransferases (KMTs) and protein arginine methyltransferases (PRMTs). Whereas methylation of some lysine residues is associated with activation of gene transcription (e.g., H3K4, H3K36, and H3K79), methylation of other residues is associated with repression of gene transcription (e.g., H3K9, H3K20, and H3K27) [13-15]. Some histone modifications are enriched at distinct regions (i.e., enhancer, promoter, or coding sequences) of the gene, though H3K27me3 is distributed widely across enhancers and promoters [16]. Moreover, mono-, di-, or tri-methylation of a single residue can alter the affinity of "reader" proteins to the methylated histones and may have distinct functional consequences [17].

In particular, tri-methylation of the lysine at the 27 th amino acid on histone $\mathrm{H} 3$ (H3K27me3) is a critical determinant of chromatin accessibility and gene expression. The "writer" of H3K27me3, enhancer of zeste 2 (EZH2) (Figure 1), has been known to be involved in tumor progression in an oncogenic capacity for over twenty years [18-20]. Detailed reviews concerning the activity and history of the H3K27me3 methyltransferases, EZH1 and EZH2, are available [21,22]. Nevertheless, the more recent uncovering of Jumonji-domain-containing proteins, which are capable of catalyzing the demethylation of H3K27me3, has revealed additional complexity surrounding H3K27me3 (Figure 1).

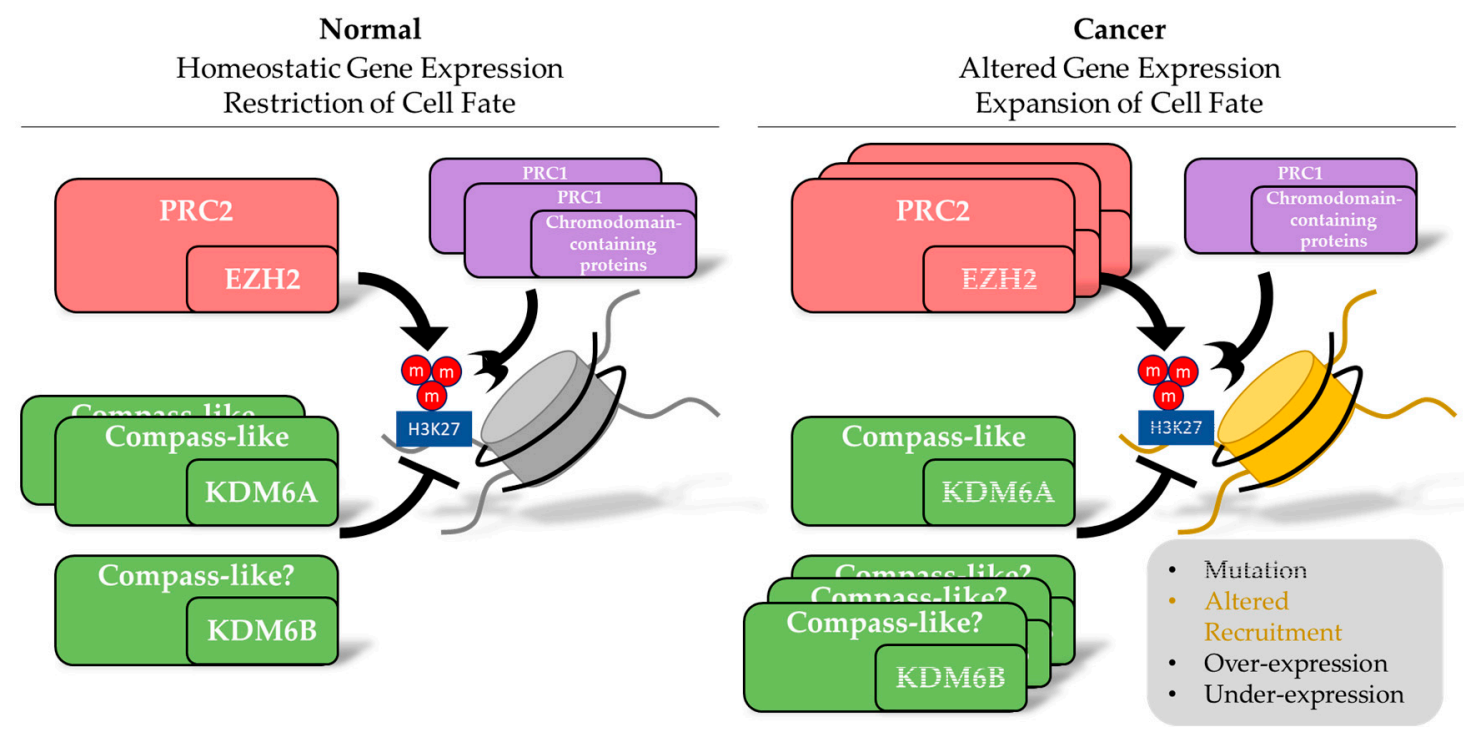

Figure 1. Regulated addition and removal of H3K27me3 is critical for maintaining cellular homeostasis. Functioning as members of protein complexes, the indicated enzymes possess the biochemical activity to alter the methylation state at H3K27 while chromodomain-containing proteins, among others, have the capacity to interpret the methylation state. Disruption in this balance, whether through mutations (indicated by strikethroughs), altered recruitment (indicated by change in nucleosome color), over-expression (indicated by additional boxes) or under-expression (indicated by fewer boxes), has the potential to drive and/or support tumorigenesis through the expansion of cell fate identity. 


\subsection{Molecular Mechanisms}

The primary H3K27me3 "writer" protein, EZH2, is the enzymatic component of the polycomb repressor complex 2 (PRC2) and is capable of catalyzing methylation of non-methylated H3K27 to either a di- or tri-methylated state. The C-terminal SET domain of EZH2 exhibits the methyltransferase activity. Along with EZH2, additional proteins including EED, SUZ12, and RBBP4/RbAp48/NURF55 comprise the core of the PRC2 complex [23] (Figure 1). All of these proteins are required for the full histone methyltransferase activity of EZH2 [23-25]. The zinc-finger containing protein, SUZ12, and WD40 repeat protein, EED, together maintain the structural integrity of PRC2 complex and methyltransferase activity of EZH2. Additional PRC2 components that fall outside the core complex include AEP2, PCL (PHF), and JARID2 which appear to be accessory factors for PRC2 enzymatic activity. The PRC2 subcomplex, which lacks the fourth core component RBBP4/RbAp48/NURF55 can nevertheless perform substantial enzymatic activity. EZH2 is post-translationally regulated by O-linked $\mathrm{N}$-acetylglucosamine (GlcNAc) transferase (OGT)-mediated O-GlcNAcylation at S75, which stabilizes EZH2 and facilitates the formation of H3K27me3 [26]. Although, EZH1 is a paralog of EZH2, the EZH1-loaded PRC2 complex has a distinct cellular function, primarily as a maintainer of the repressed chromatin state. Indeed, EZH1 is ubiquitously expressed, whereas EZH2 is expressed primarily in proliferating cells. These observations suggest that EZH1-PRC2 containing complexes might contribute in the restoration of the H3K27 methylation after histone demethylation or histone exchanges [23,27]. H3K27me3 is detected by specific binding of chromodomain-containing protein, $\mathrm{CBX}$, in the polycomb repressor complex 1 (PRC1). A component of PRC1 (Ring1b) then mediates mono-ubiquitination of H2A at K119 [28]. This modification (H2AK119ub1) is required for PRC-dependent silencing and functions to inhibit RNA polymerase II elongation [29].

In contrast to other histone modifications such as phosphorylation and acetylation, methylation and especially trimethylation, have been considered irreversible because of the high thermodynamic stability of the $\mathrm{N}-\mathrm{CH}_{3}$ bond [30-32]. Nevertheless, while lysine demethylases (KDMs) were first detected in the 1960s in rat kidney extracts, it took four decades to identify specific proteins with such activity. The first such enzyme described, Lysine-Specific Demethylase 1 (initially named LSD1 and then re-named to KDM1A), is an amine oxidase that can demethylate di- or mono-methylated H3K4 [30,31,33-35]. However, a second discovery uncovered a much larger class of lysine-specific demethylases which are categorized as Jumonji C (JmjC) domain-containing (JMJD) proteins. To date around $30 \mathrm{KDMs}$ have been identified and characterized [36]. Based on their mechanism of action, KDMs can be classified into two families: (1) Flavin adenine dinucleotide (FAD)-dependent, which can catalyze the oxidation of a methyl amine group to generate an iminium cation, and (2) Fe (II) and 2-oxoglutarate (2OG)-dependent, which can catalyze reactions by converting the methyl group into a hydroxymethyl group, then released as formaldehyde [30,37-39]. The FAD-dependent family KDM1 (KDM1A and KDM1B) can only catalyze the demethylation of mono- and di-methylated lysine (Kme1 and Kme2), unlike the Fe (II) and 2OG-dependent family of KDMs (KDM 2-7), which are capable of demethylating Kme1, Kme2 and Kme3 [40,41]. A series of magnificent reviews have provided a detailed and extensive characterization of individual histone demethylases, their substrates and their roles in normal development and diseases [36,41-44].

\subsection{Intersection with DNA Methylation}

Methylation at the $5^{\prime}$ position of cytosine residues within the DNA $(5 \mathrm{mC})$ is an epigenetic mark that can also alter gene expression. When present in promoter regions, $5 \mathrm{mC}$ typically suppresses gene expression by recruiting the methyl binding proteins and modulation of transcription machinery access. $5 \mathrm{mC}$ is an important mechanism in normal cell development, by playing roles in regulation of gene expression, $\mathrm{X}$-chromosome inactivation, genetic imprinting, and the suppression of repetitive element transcription and transposition. Aberrant $5 \mathrm{mC}$ may occur through hypermethylation in the promoter regions of tumor suppressor genes, resulting in silencing of that gene or hypomethylation in the promoter regions of oncogenes, activating them. 
Though similar in their effect on transcriptional output, $5 \mathrm{mC}$ and H3K27me3 are used in distinct regions across the genome. At CpG-rich regions of the genome $5 \mathrm{mC}$ and $\mathrm{H} 3 \mathrm{~K} 27 \mathrm{me} 3$ show little overlap in both normal and cancer cells, a phenomenon which may be explained by diminished binding of the PRC2 complex to chromatin enriched with $5 \mathrm{mC}[45,46]$. However, at CpG-poor regions, silenced chromatin frequently contains both $5 \mathrm{mC}$ and H3K27me3 [47].

Biochemically, $5 \mathrm{mC}$ and $\mathrm{H} 3 \mathrm{~K} 27 \mathrm{me} 3$ are intimately linked. The conversion of $5 \mathrm{mC}$ into an oxidized form capable of replacement through base-excision repair is accomplished by the TET family of enzymes and is dependent on $\mathrm{O}_{2}, \mathrm{Fe}(\mathrm{II})$, and 2-OG [48] through a similar mechanism to that which is used by the JmjC lysine de-methylases. Thus, levels of oxygen, iron, and metabolites can affect the stability of both $5 \mathrm{mC}$ and $\mathrm{H} 3 \mathrm{~K} 27 \mathrm{me} 3$. Furthermore, the established $5 \mathrm{mC}$ reader protein, $\mathrm{MeCP} 2$, was recently shown to also bind to H3K27me3-enriched nucleosomes [49], illustrating conservation in the two transcription silencing mechanisms.

\subsection{Developmental Roles}

The discovery of the reader and writer protein complexes for H3K27me3 as mutants that disrupt developmental patterning in the fruit fly illustrates how important this residue is in developmental processes. In mice, loss of PRC2 components EZH2, EED, or SUZ12 leads to early embryonic lethality due to the embryos failing to undergo gastrulation [50-52]. Studies of conditional and tissue-specific knockout mice demonstrate the importance of PRC2 in orchestrating cellular differentiation in a range of tissues. PRC2 maintains the integrity of cellular identity and loss of essential component proteins makes differentiation more labile [21,53,54]. During embryogenesis, H3K27me3 patterns emerge during the morulae stage and reach their peak in blastocytes [55]. H3K27me3 is widely distributed in a non-canonical pattern among intergenic spacers and gene deserts [56,57]. After fertilization, the paternal H3K27me3 mark is largely removed from the promoter regions of development-related genes, while the maternal mark retained. This allele-specific differential H3K27me3 modification persists till the blastocyst stages [55,58].

Methylation of H3K27 is an important mechanism in the maintenance of self-renewing embryonic stem cells (ESCs) by repressing the differentiation pathway. For instance, a decrease in H3K27me3 levels is seen at the promoter of UTX (Ubiquitously Transcribed Tetratricopeptide Repeat on chromosome $\mathrm{X}$ ) during the differentiation of wild-type ESCs. Additionally, epigenomic analyses suggest that ESCs possess genes with promoters that have abundant H3K27me3 along with a high level of transcription-activating $\mathrm{H} 3 \mathrm{~K} 4 \mathrm{me} 3$. In these cases, the presence of $\mathrm{H} 3 \mathrm{~K} 27 \mathrm{me} 3$ at the transcription start site results in transcriptional repression. However, such domains, termed "bivalent" are poised for rapid transcriptional activation facilitating differentiation towards diverse cell fates. Not only are genes with bivalent domains enriched in ESCs [59], they are also enriched in cancer stem cells which also possess the ability to differentiate into multiple cell fates [60].

\section{Alterations in Inducers of Methylation of H3K27 in Cancer}

The methylation of H3K27 is a critical contributor to transcriptional repression in many biological processes including genomic imprinting, $\mathrm{X}$-chromosome inactivation in females, stem cell maintenance and differentiation, circadian rhythm, and especially cancer [61,62]. Not surprisingly, loss of homeostasis in this pathway has emerged as a recurrent theme in the pathogenesis of many cancers.

Epigenetic regulators, considering their importance during normal stem cell maintenance, are typically hijacked to sustain malignant properties. The preponderance of evidence suggests that EZH2 acts as an oncogene and its aberrant over-expression and deregulation of function are documented across multiple varieties of solid tumors, including breast, ovarian, pancreas, prostate, bladder, renal, brain, kidney, gastric, and lung malignancies [23,63-73] (Table 1). Additionally, EZH2 overexpression has been shown to promote migration, cell proliferation and invasion in different in vitro cancer models [74-76]. Pointing to a direct role of increased H3K27me3 in the oncogenic capacity of EZH2, the oncogenicity of EZH2, in in vivo models, correlates with its H3K27 methyltransferase activity [77]. 
Complicating the story, both gain- and loss-of-function mutations in EZH2 are frequent in various types of cancer including lymphomas, melanoma, and myelodysplastic lymphoma (MDS) [22,78]. The gain-of-function mutations in EZH2 often lead to a hyperactive methyltransferase enzyme, resulting in extensive H3K27 trimethylation, promoting chromatin restriction and blocking cell differentiation [62].

Table 1. EZH2 alterations by cancer type. Data on expression status was collected from studies deposited in Oncomine (http://www.oncomine.org/) or in the scientific literature. Data on mutation, gene amplification, and deletion were collected from the TCGA PanCancer dataset using cBioPortal $[79,80]$. Cancer types with alteration at EZH2 in at least $2 \%$ of cases are shown. All mutations within the SET domain or truncating mutations prior to the SET domain were considered to compromise enzymatic activity.

\begin{tabular}{|c|c|c|c|c|c|c|}
\hline \multicolumn{7}{|c|}{$E Z H 2$} \\
\hline \multirow{2}{*}{$\begin{array}{l}\text { Cancer Types with } \\
\text { Evidence of Altered } \\
\text { Expression or with Gene } \\
\text { Altered in at Least } 2 \% \\
\text { of Cases }\end{array}$} & \multirow[b]{2}{*}{$\begin{array}{l}\text { Altered } \\
\text { Expression }\end{array}$} & \multicolumn{5}{|c|}{ Cases in TCGA PAN-CANCER } \\
\hline & & Amplification & Fusion & $\begin{array}{c}\text { Deep } \\
\text { Deletion }\end{array}$ & Mutation & $\begin{array}{c}\% \text { of } \\
\text { Mutations } \\
\text { Affecting the } \\
\text { SET Domain }\end{array}$ \\
\hline Prostate Adenocarcinoma & $\uparrow[64,66,81]$ & $0.80 \%$ & - & $0.20 \%$ & - & - \\
\hline $\begin{array}{c}\text { Invasive Breast } \\
\text { Carcinoma }\end{array}$ & $\uparrow$ TCGA [82] & $0.65 \%$ & - & $0.46 \%$ & $0.28 \%$ & $100 \%$ \\
\hline Colon Adenocarcinoma & $\uparrow[83,84]$ & - & - & - & $1.85 \%$ & $17 \%$ \\
\hline $\begin{array}{l}\text { Hepatocellular } \\
\text { Carcinoma }\end{array}$ & $\uparrow[85]$ & $0.81 \%$ & - & $0.54 \%$ & $0.27 \%$ & $100 \%$ \\
\hline Endometrial Carcinoma & $\uparrow[69]$ & $0.50 \%$ & - & - & $7.50 \%$ & $31 \%$ \\
\hline $\begin{array}{l}\text { Clear Cell Renal } \\
\text { Carcinoma }\end{array}$ & $\uparrow[86]$ & $0.59 \%$ & - & - & $0.39 \%$ & $0 \%$ \\
\hline Ovarian Epithelial & $\uparrow[$ TCGA] [87] & $7.00 \%$ & - & $0.30 \%$ & $0.30 \%$ & $0 \%$ \\
\hline Melanoma & $\uparrow[69]$ & $2.00 \%$ & - & $0.20 \%$ & $4.70 \%$ & $21 \%$ \\
\hline Sarcoma & $\uparrow[88,89]$ & $1.96 \%$ & - & $2.35 \%$ & $0.39 \%$ & $100 \%$ \\
\hline Cervical Carcinoma & $\uparrow[90-92]$ & - & - & - & $4.35 \%$ & $0 \%$ \\
\hline Lung Adenocarcinoma & $\uparrow[93]$ & $1.04 \%$ & $0.28 \%$ & $0.38 \%$ & $1.61 \%$ & $0 \%$ \\
\hline $\begin{array}{l}\text { Esophagogastric } \\
\text { Adenocarcinoma }\end{array}$ & & $0.19 \%$ & - & $1.56 \%$ & $1.17 \%$ & $0 \%$ \\
\hline Glioblastoma & $\begin{array}{c}\uparrow \text { TCGA } \\
\downarrow[94]\end{array}$ & $1.86 \%$ & - & - & $0.68 \%$ & $25 \%$ \\
\hline Leukemia & $\begin{array}{c}\uparrow[95] \\
\downarrow C L L[96-98]\end{array}$ & - & - & $1.00 \%$ & $1.00 \%$ & $25 \%$ \\
\hline $\begin{array}{l}\text { Bladder Urothelial } \\
\text { Carcinoma }\end{array}$ & $\uparrow[99]$ & $0.49 \%$ & - & $0.49 \%$ & $1.46 \%$ & $40 \%$ \\
\hline $\begin{array}{l}\text { Adrenocortical } \\
\text { Carcinoma }\end{array}$ & $\uparrow[100]$ & $1.10 \%$ & - & $1.10 \%$ & - & - \\
\hline $\begin{array}{l}\text { Esophageal Squamous } \\
\text { Cell Carcinoma }\end{array}$ & $\uparrow[101]$ & $1.05 \%$ & - & $1.05 \%$ & - & - \\
\hline Mature B-Cell Neoplasms & & - & - & - & $2.08 \%$ & $0 \%$ \\
\hline Cholangiocarcinoma & & - & - & - & $2.78 \%$ & $0 \%$ \\
\hline
\end{tabular}

In hematological malignancies, the role of EZH2 may be either oncogenic or tumor suppressive [102,103]. The over-expression of mutant EZH2 has been reported in a wide variety of B-and T-cell lymphoproliferative disorders [103-106]. In chronic lymphocytic leukemia (CLL), studies into the role of PRC2 components in hematopoietic stem cells (HSCs) have been somewhat contradictory. While gain-of function studies by Kamminga et al. and Herrera-Merchan et al. suggest it has an important role in self-renewal regulation [95,107], knockout of $E Z H 2$ in mice by O'Carroll et al. demonstrated no effect on HSCs, although development of B and T cells was affected [50]. While the reason for these conflicting results remains to be determined, some evidence shows that in adult HSCs, EZH1 can compensate for EZH2 loss, which can help to explain these discrepancies [108]. Although many studies use cell lines, primary cells and mouse models of CML have shown dysregulated expression, but no mutations in the PRC2 components [102]. In MDS and MDS-derived acute myeloid leukemia (AML), EZH2 over-expression is correlated with poor prognosis. Xu et al. describe that 
MDS and MDS-derived AML harbor a specific DNA methylation of the tumor suppressor gene INK4B (p15) [109]. Patients with methylation at this gene have statistically higher relative mean expression of EZH2 compared with patients without methylated INK4B. According to International Prognostic Scoring System, the level of EZH2 expression is positively correlated with poor disease outcome $[103,109,110]$. The over-expression of EZH2 is not enough to cause leukemia, but it does prevent the clearance of HSCs [95]. Overexpression of EZH2 may also be caused by a variety of transcriptional pathways, some of them are specific to particular malignancies, while others are more common.

EZH2 has a well-described oncogenic function in solid cancers. In triple-negative breast cancer overexpression of EZH2 is found to be a result of MEK-ERK-ELK1 pathway activation. Phosphorylated ELK1 binds three ELK1-binding motifs within the EZH2 promoter and activates EZH2 transcription. In bladder cancer, small-cell lung cancer and breast malignancies, EZH2 dysregulation is related to the deregulation of pRb-E2F pathway or overexpression of E2F [27,111-113]. Additionally, MYC and ETS transcription factors in prostate cancer [113,114], NF-YA in epithelial ovarian cancer [115], and STAT3 in colorectal cancer [23] regulate EZH2 expression, while the fusion oncoprotein EWS-FLI1 induces EZH2 expression in Ewing's sarcoma [116]. Hypoxia in solid tumors can be another potential regulator of EZH2 transcription. Chang et al. identified a consensus sequence for hypoxia-inducible factor- $1 \alpha$ (HIF-1 $\alpha$ ) within the EZH2 promoter [117]. Along with these signaling pathways, EZH2 expression can be controlled post-transcriptionally by multiple micro-RNAs (miR-25, -26a, -30d, - 144, -214, -138, -137 , let-7, etc.). These miRs can downregulate EZH2 by interacting with its 3'UTR sequence, thus, dysregulation of these miRs can up-regulate the EZH2 expression driving cancer progression [118-129]. An increase in H3K27me3 can also be the result of increased recruitment of PRC2 complex to chromatin. Long non-coding RNAs (lncRNAs) are one of the potential factors in this regard. In particular, HOTAIR along with several other lncRNAs such as HEIH, PCAT-1, and H19 etc. [130-135], play oncogenic roles by interacting with PRC2 to recruit EZH2 to target genes in various cancers.

Altered EZH2 activity may also be due to gain-of-function (GOF) mutations. In their landmark study, Morin et al. describe GOF point mutations resulting from a switch from tyrosine to histidine at codon 641 which lies in the catalytically active SET domain of the EZH2 protein [104]. This study demonstrated that Tyr641 (Y641) mutations (Y641F, Y641N, Y641S, Y641C and Y641H) [22], while associated with significant reduction of EZH2 enzymatic activity, nevertheless resulted in an increase in global H3K27me3, possibly due to a change in substrate preference to favor H3K27me2 over H3K27me0/1 [103,136,137]. The oncogenic potential of this mutation is well established and has been found in $7.2 \%$ of follicular lymphoma and $21.7 \%$ of diffuse large B-cell lymphoma (DLBCL) [106,138-140]. Additional support for an oncogenic role for EZH2 in cancer comes from the loss-of-function mutations of other cancer associated chromatin regulators that normally antagonize EZH2 activity. In malignant rhabdoid tumors, which are highly aggressive pediatric cancers, loss of the SWI-SNF core subunit SNF5 (also known as SMARCB1) results in unopposed EZH2 activity [22,141,142]. Studies from different laboratories extend this antagonistic model in different cancers. Mutation in the SWI-SNF subunit ARIDIA causes synthetic lethality during the inhibition of EZH2 in ovarian cancer xenograft. Furthermore, inhibition of EZH2 in lung cancer xenograft having SWI-SNF subunit BRG1 mutation sensitizes to chemotherapy $[143,144]$. In addition to methylation of H3K27, EZH2 has been shown to possess oncogenic activity through its ability to methylate cellular proteins and act as a co-activator of steroid hormone receptors. This modification requires an intact methyltransferase domain and phosphorylation of EZH2 [145]. This function is hypothesized to be independent of PRC2 and potentially induced by phosphorylation of EZH2 $[145,146]$.

Although the frequency of overexpression and gain-of-function mutations suggests an oncogenic role for EZH2, there is also evidence suggesting that EZH2 acts as a tumor suppressor in some cancers [22,147-149]. Both monoallelic and biallelic mutations (missense mutation, frameshift mutation, premature stop codons and splicesomal mutations) of EZH2 have been identified in around $23 \%$ of various subtypes of MDS, myeloproliferative neoplasms (MPN), and MDS-MPN overlap 
disorders [150-153] (Table 1). Almost all mutations are predicated to inactivate the methyltransferase activity. Individuals having homozygous mutations have reduced survival compared to those having heterozygous mutations. Furthermore, loss-of-function mutations and deletions of EZH2 are also detectable in other cancers including T-lineage acute lymphoblastic leukemia (T-ALL) and core binding factor acute myeloid leukemia. Notably, EZH2 is not the only PRC2 subunit affected in these cancers, as missense mutations have also been identified in SUZ12 [152,154,155].

Clearly, most tumor types use EZH2 in support of tumor growth, yet EZH2 loss also occurs, particularly in some myelodysplastic syndromes, and mutations can drive neomorphic activity, particularly in lymphomas. Still, not all blood cancers lose or alter EZH2 activity. Whether frequency of co-mutations, effects on protein localization, or other alterations in the PRC2 complex members can explain these disparities remains to be seen.

\section{KDM6 Family-Molecular Functions}

Histone lysine methylation was long considered a stable covalent modification due to its low turnover rate relative to other post-translational modifications [30,31]. Nevertheless, two proteins with known demethylase activity can remove H3K27me3: KDM6A, previously known as ubiquitously transcribed tetratricopeptide repeat X (UTX) and KMD6B, previously known as Jumonji domain-containing protein D3 (JMJD3) [156-160]. KDM6A consists of 1401 amino acids and contains a JmjC catalytic domain and 6 tetratricopeptide repeat (TPR) protein-protein interaction domains. KDM6B consists of 1679 amino acids, with only a JmjC domain characterized $[159,161]$. However, sequence analysis suggests that it may also contain TPR domains like KDM6A [162,163]. A third member of this protein family, KDM6C, which was previously known as UTY, consists of 1347 amino acids, has $83 \%$ amino acid homology with KDM6A and was once thought to lack demethylase activity $[157,162,164]$. However, recently it has been demonstrated that it has minimal demethylase activity due to a subtle sequence diversity in the JmjC domain [164]. KDM6C is located on the $\mathrm{Y}$ chromosome and, as shown in a knock-out mouse model, it can partially compensate for some of the demethylase-independent functions of KDM6A [165]. KDM6C may activate transcription in a gene-specific manner and it is thought that this demethylase may be required for male sex determination during embryonic development $[162,164]$. Furthermore, KDM6A is distinct from $\mathrm{KDM} 6 \mathrm{~B}$ in a functional sense in that its activity is more dependent upon $\mathrm{O}_{2}$ concentration [166]. Indeed, hypoxia induces an increase in H3K27me3 which is mediated by loss of KDM6A activity, independent of the canonical HIF- $1 \alpha$ response [166].

It has been established that KDM6A associates with KMT2-related H3K4 methylating proteins in the Compass-like complex (Figure 1). In 2007, an KMT22 complex was identified in different mammalian cell types containing 12 protein members including KMT22, PTIP, UTX/KDM6A, RBBP5, WDR5, DPY30, ASC-2, ASHL2L, martin 3, MGC4606, alpha- and beta-tubulin [167]. Furthermore, KDM6A, KMT22 and PTIP co-localize at the promoter regions and first exon of KMT22 target genes, which is marked with H3K4me3 [167]. Another group confirmed a similar H3K4me3 methyltransferase complex containing KMT22, KMT23, KDM6A, PTIP, ASC-2, PAI, ASH2L, RBBP5, DPY30, and WDR5 [168]. Interestingly, the composition of this KMT22 complex was conserved with Drosophila ortholog Trithorax related (trr) complex [169] and C. elegans ortholog SET-16 complex [170]. This finding suggests a tight coupling in the reciprocal relationship of H3K4 and H3K27 tri-methylation during transcriptional gene regulation $[61,167,171]$. Although aspects of their biochemical regulation still remain to be determined, demethylase enzymes like KDM6A and KDM6B are often genetically inactivated in various types of cancers [7,172] (Tables 2 and 3). Therefore, it is reasonable to hypothesize that homeostasis between EZH2 and KDM6A/B activity is necessary for maintaining normal cell activity or phenotype (Figure 1).

\section{Alterations in the Erasers of Methylation of H3K27 in Cancer}

Depending on the cell or cancer type KDM6 family members have both oncogenic and tumor-suppressor roles in cancer [61,173-176]. KDM6A was initially characterized as a 
tumor-suppressor, which can repress Notch and $\mathrm{Rb}$-induced tumors in Drosophila [173,177]. Interaction between $\mathrm{Rb}$ and KDM6A was also demonstrated in human cells. Loss-of function mutations and deletions targeting KDM6A have been reported in medulloblastoma [178], T-cell acute lymphoblastic leukemia (T-ALL) [175,176], acute lymphoblastic leukemia (ALL) [175,179], renal cell carcinoma [180], bladder cancer [181,182], chronic myelomonocytic leukemia (CMML) [153], multiple melanoma [183], and many other solid and non-solid tumors [183] (Table 2).

Table 2. KDM6A alterations by cancer type. Data on expression status was collected from studies deposited in Oncomine (http://www.oncomine.org/) or in the scientific literature. Data on mutation, gene amplification, and deletion were collected from the TCGA PanCancer dataset using cBioPortal $[79,80]$. Cancer types with alteration at KDM6A in at least $2 \%$ of cases are shown. All mutations within the JmjC domain or truncating mutations prior to the JmjC domain were considered to compromise enzymatic activity.

\begin{tabular}{|c|c|c|c|c|c|c|}
\hline \multicolumn{7}{|c|}{ KDM6A } \\
\hline \multirow{2}{*}{$\begin{array}{l}\text { Cancer Types with } \\
\text { Evidence of Altered } \\
\text { Expression or with Gene } \\
\text { Altered in at Least } 2 \% \\
\text { of Cases }\end{array}$} & \multirow[b]{2}{*}{$\begin{array}{c}\text { Altered } \\
\text { Expression }\end{array}$} & \multicolumn{5}{|c|}{ Cases in TCGA PAN-CANCER } \\
\hline & & Amplification & Fusion & $\begin{array}{c}\text { Deep } \\
\text { Deletion }\end{array}$ & Mutation & $\begin{array}{c}\% \text { of } \\
\text { Mutations } \\
\text { Affecting the } \\
\text { JmjC Domain }\end{array}$ \\
\hline $\begin{array}{l}\text { Bladder Urothelial } \\
\text { Carcinoma }\end{array}$ & $\uparrow[184]$ & $0.49 \%$ & - & $2.68 \%$ & $25.55 \%$ & $74 \%$ \\
\hline $\begin{array}{l}\text { Esophageal Squamous } \\
\text { Cell Carcinoma }\end{array}$ & $\downarrow[101]$ & $1.05 \%$ & - & $11.58 \%$ & $3.16 \%$ & $25 \%$ \\
\hline $\begin{array}{l}\text { Non-Small Cell Lung } \\
\text { Cancer }\end{array}$ & & $0.85 \%$ & $0.09 \%$ & $2.18 \%$ & $3.23 \%$ & $49 \%$ \\
\hline $\begin{array}{c}\text { Endometrial Carcinoma } \\
\text { Head and Neck }\end{array}$ & & $0.85 \%$ & - & $0.68 \%$ & $6.66 \%$ & $22 \%$ \\
\hline $\begin{array}{c}\text { Squamous Cell } \\
\text { Carcinoma }\end{array}$ & $\downarrow[185]$ & $0.19 \%$ & - & $3.25 \%$ & $3.44 \%$ & $65 \%$ \\
\hline $\begin{array}{c}\text { Pancreatic } \\
\text { Adenocarcinoma }\end{array}$ & & - & - & $2.72 \%$ & $3.80 \%$ & $86 \%$ \\
\hline $\begin{array}{c}\text { Stomach } \\
\text { Adenocarcinoma }\end{array}$ & & $0.68 \%$ & - & $1.82 \%$ & $3.41 \%$ & $40 \%$ \\
\hline Melanoma & $\downarrow[186]$ & - & - & $0.23 \%$ & $5.18 \%$ & $11 \%$ \\
\hline $\begin{array}{c}\text { Cervical Squamous Cell } \\
\text { Carcinoma }\end{array}$ & & $0.34 \%$ & - & $1.35 \%$ & $3.03 \%$ & $40 \%$ \\
\hline Prostate Adenocarcinoma & $\uparrow[187]$ & $0.20 \%$ & - & $1.21 \%$ & $2.02 \%$ & $25 \%$ \\
\hline Mature B-Cell Neoplasms & & $2.08 \%$ & - & - & $2.08 \%$ & $0 \%$ \\
\hline Ovarian Epithelial Tumor & $\downarrow[188]$ & $2.23 \%$ & $0.17 \%$ & $1.03 \%$ & $0.68 \%$ & $33 \%$ \\
\hline Lung Adenocarcinoma & & $0.88 \%$ & $0.18 \%$ & $0.71 \%$ & $1.94 \%$ & $31 \%$ \\
\hline $\begin{array}{l}\text { Esophagogastric } \\
\text { Adenocarcinoma }\end{array}$ & & $0.97 \%$ & - & $1.95 \%$ & $3.50 \%$ & $0 \%$ \\
\hline $\begin{array}{c}\text { Colorectal } \\
\text { Adenocarcinoma }\end{array}$ & & $0.17 \%$ & $0.51 \%$ & - & $2.53 \%$ & $33 \%$ \\
\hline $\begin{array}{l}\text { Renal Non-Clear Cell } \\
\text { Carcinoma }\end{array}$ & & - & - & - & $3.16 \%$ & $0 \%$ \\
\hline Sarcoma & & $1.18 \%$ & - & $0.78 \%$ & $0.39 \%$ & $25 \%$ \\
\hline $\begin{array}{l}\text { Hepatocellular } \\
\text { Carcinoma }\end{array}$ & & $0.54 \%$ & - & $1.63 \%$ & $0.81 \%$ & $33 \%$ \\
\hline $\begin{array}{l}\text { Invasive Breast } \\
\text { Carcinoma }\end{array}$ & $\uparrow[189]$ & $0.65 \%$ & $0.09 \%$ & $0.18 \%$ & $1.94 \%$ & $0 \%$ \\
\hline Leukemia & $\begin{array}{c}\uparrow \text { Adult T-cell } \\
{[190]}\end{array}$ & $0.50 \%$ & - & $0.50 \%$ & $1.50 \%$ & $0 \%$ \\
\hline Pleural Mesothelioma & & - & - & $1.15 \%$ & $1.15 \%$ & $0 \%$ \\
\hline Cervical Adenocarcinoma & & - & - & - & $2.17 \%$ & $29 \%$ \\
\hline
\end{tabular}

Genetic loss of KDM6A, co-occurring with aberrant TLX3 expression in T-ALL, accelerates the initiation and progression of leukemia and decreases the life span in NOTCH1-overexpressing experimental mice $[175,176,191]$. Overexpression of KDM6A also decreases growth and induces apoptosis in T-ALL cell lines [176]. Tying this result to its H3K27me3 demethylase activity, loss of KDM6A leads to accumulation of $\mathrm{H} 3 \mathrm{~K} 27 \mathrm{me} 3$ at the promoters of putative tumor suppresser genes, 
including FBXW7 and RBBP6 [173,175]. Additionally, the effects of KDM6A knockdown are also reported to be dependent on EZH2 activity as they can be blocked by the EZH2 inhibitor 3-DZNep [192].

Surprisingly, KDM6B, in contrast to KDM6A, acts as an oncogene in NOTCH1 overexpressing T-ALL cancer (Table 3) [192]. ChIP studies reveal that KDM6B is bound to NOTCH1 targets with oncogenic functions (HEY1, NRARP and HES1). Indeed, knockdown of KDM6B affects the viability of leukemic cells. Consistent with its function as a transcription activator, genome-wide analysis shows that more transcripts are significantly downregulated than are upregulated by KDM6B knockdown. Nevertheless, one hypothesis that may explain the oncogenic function of KDM6B in T-ALL, versus the tumor suppressive function of KDM6A in T-ALL, could be the lack of N-terminal TPR domain in KDM6B, but the exact cause and mechanism is yet to be explored $[175,193]$.

Table 3. KDM6B alterations by cancer type. Data on expression status was collected from studies deposited in Oncomine (http://www.oncomine.org/) or in the scientific literature. Data on mutation, gene amplification, and deletion were collected from the TCGA PanCancer dataset using cBioPortal $[79,80]$. Cancer types with alteration at KDM6A in at least $2 \%$ of cases are shown. All mutations within the JmjC domain or truncating mutations prior to the JmjC domain were considered to compromise enzymatic activity.

\begin{tabular}{|c|c|c|c|c|c|c|}
\hline \multicolumn{7}{|c|}{ KDM6B } \\
\hline \multirow{2}{*}{$\begin{array}{l}\text { Cancer Types with } \\
\text { Evidence of Altered } \\
\text { Expression or with } \\
\text { Gene Altered in at } \\
\text { Least } 2 \% \text { of Cases }\end{array}$} & \multirow[b]{2}{*}{$\begin{array}{l}\text { Altered } \\
\text { Expression }\end{array}$} & \multicolumn{5}{|c|}{ Cases in TCGA PAN-CANCER } \\
\hline & & Amplification & Fusion & $\begin{array}{c}\text { Deep } \\
\text { Deletion }\end{array}$ & Mutation & $\begin{array}{c}\% \text { of } \\
\text { Mutations } \\
\text { Affecting the } \\
\text { JmjC Domain }\end{array}$ \\
\hline Papillary Renal Cell & $\uparrow[194]$ & - & - & $0.35 \%$ & $1.06 \%$ & $66 \%$ \\
\hline Oligodendroglioma & $\uparrow[195]$ & - & - & - & - & - \\
\hline Melanoma & & - & - & $0.45 \%$ & $8.33 \%$ & $13 \%$ \\
\hline Endometrial carcinoma & & $0.17 \%$ & - & $0.17 \%$ & $7.68 \%$ & $19 \%$ \\
\hline $\begin{array}{c}\text { Miscellaneous } \\
\text { Neuroepithelial Tumor }\end{array}$ & & - & - & $3.23 \%$ & $3.23 \%$ & $0 \%$ \\
\hline $\begin{array}{l}\text { Colorectal } \\
\text { Adenocarcinoma }\end{array}$ & & - & - & $1.18 \%$ & $4.21 \%$ & $38 \%$ \\
\hline $\begin{array}{l}\text { Esophagogastric } \\
\text { Adenocarcinoma }\end{array}$ & & $0.19 \%$ & - & $0.58 \%$ & $4.09 \%$ & $0 \%$ \\
\hline $\begin{array}{c}\text { Prostate } \\
\text { Adenocarcinoma }\end{array}$ & $\uparrow[196]$ & - & - & $4.05 \%$ & $0.81 \%$ & $25 \%$ \\
\hline $\begin{array}{l}\text { Esophageal Squamous } \\
\text { Cell Carcinoma }\end{array}$ & & $1.05 \%$ & - & $1.05 \%$ & $2.11 \%$ & $50 \%$ \\
\hline Sarcoma & & $1.57 \%$ & - & $1.18 \%$ & $0.78 \%$ & $0 \%$ \\
\hline $\begin{array}{l}\text { Adrenocortical } \\
\text { Carcinoma }\end{array}$ & & - & - & $1.10 \%$ & $2.20 \%$ & $0 \%$ \\
\hline $\begin{array}{l}\text { Hepatocellular } \\
\text { Carcinoma }\end{array}$ & $\uparrow[197]$ & - & - & $2.44 \%$ & $0.54 \%$ & $0 \%$ \\
\hline $\begin{array}{c}\text { Non-Small Cell Lung } \\
\text { Cancer }\end{array}$ & & $0.09 \%$ & - & $0.76 \%$ & $1.99 \%$ & $0 \%$ \\
\hline $\begin{array}{l}\text { Bladder Urothelial } \\
\text { Carcinoma }\end{array}$ & & - & - & $0.97 \%$ & $1.70 \%$ & $14 \%$ \\
\hline $\begin{array}{c}\text { Cervical Squamous Cell } \\
\text { Carcinoma }\end{array}$ & & - & - & $0.40 \%$ & $1.99 \%$ & $0 \%$ \\
\hline $\begin{array}{c}\text { Cervical } \\
\text { Adenocarcinoma }\end{array}$ & & - & - & $2.17 \%$ & - & - \\
\hline T-Cell Lymphomas & $\downarrow[198]$ & - & - & - & - & - \\
\hline $\begin{array}{l}\text { Mature B-Cell } \\
\text { Neoplasms }\end{array}$ & $\downarrow[97]$ & - & - & $2.08 \%$ & - & - \\
\hline
\end{tabular}

KDM6A is not a tumor suppressor in all T-ALL molecular subtypes. In cases of T-ALL that are driven by transcription factor TAL1, KDM6A acts as a coactivator for oncogenic reprogramming [192]. In myeloid leukemia, suppression by KDM6A depends on its non-catalytic activity. KDM6A helps to suppress the effect of ETS (E-twenty-six), while supporting the activation of those targeted by GATA transcriptional programs, mainly driven by GATA2 [199]. These effects mainly impact the enhancers [200]. 
Bladder cancer has one of the highest frequencies of KDM6A mutations, which are typically truncating mutations compromising the catalytic JmjC domain. Interestingly, in almost $50 \%$ of bladder cancer cases there is a significant genetic aberration in chromatin remodeling genes, such as KMT2C (19.7\%), KMT2D (28.3\%), NCOR1, EP300 (16\%), and CREBBP (13.3\%) along with KDM6A [182]. Whole genome sequencing reveals that, in almost $25 \%$ cases, KDM6A is inactive [181,200-202]. There are divergent reports of KDM6A's role in breast cancer. Wang et al. describe that low KDM6A expression predicts poor survival in breast cancer [203], while Kim JH et al. report that high expression is associated with poor prognosis [204]. However, later studies support an oncogenic role for KDM6A as it is overexpressed in breast cancer and correlates with cancer grades $[189,205]$. Furthermore, knockdown of KDM6A decreases cancer cell proliferation, invasion, and lung colonization [162,189]. In breast cancer as well as others, the confusion concerning KDM6A's role may be attributed to its suite of protein-protein interaction (KMT2D vs LSD1/HDAC1) or whether the activity is demethylase-dependent or demethylase-independent [63].

KDM6B can also serve as a tumor suppressor or oncogene. It may act as a tumor suppressor by binding to and activating the INK4A-ARF locus [197]. When cells are exposed to oncogenic stress, the H3K27 residues at this locus can become demethylated, leading to cell cycle arrest and senescence [206,207]. Furthermore, KDM6B is located on chromosome 17 in close proximity to tumor suppressor TP53. Functional interaction between KDM6B-p53 and resulting p16 activation is well documented and deletions involving both genes are commonly found in human cancers $[173,208,209]$. On the other hand, KDM6B appears to act as an oncogene in melanoma and B-cell lymphoma [162]. Depletion of KDM6B in melanoma induces self-renewal, invasive migration, metastasis and angiogenesis [210]. Similarly, knockdown of KDM6B reduces tumor growth and induces apoptosis in diffuse large B-cell lymphoma [211]. In hepatocellular carcinoma, KDM6B is highly expressed and positively corelated with distant metastasis, tumor diameter, vascular invasion, differentiation, and poor prognoses in patients [212]. It has also been reported that KDM6B and HER2 contribute to poor prognoses of ovarian cancer by inducing cell migration and invasion through the regulation of TGF- $\beta 1[213,214]$. Upregulation of KDM6B also positively corelates with poor prognosis in gastric cancer [215]. In acute myeloid leukemia (AML) KDM6B is upregulated and correlated with poor prognosis [216]. In colon cancer, glioma cells, and esophageal squamous carcinoma KDM6B is upregulated [217-220].

Similarly, mutations (nonsense mutation, frameshift mutation, deletion, insertion etc.) in KDM6A in different cancers (renal, pancreatic, bladder, esophageal, myeloma etc.) cause the premature termination of codons and results in the loss of demethylase activity. Consequently, the loss-of-function mutations in KDM6A probably has effects analogous to EZH2 gain-of-function mutations [153,182,183,202,221].

Whether H3K27me3 demethylation is a trick or treat in cancer is highly contextual. The disparate effects caused by LOF of either KDM6A or KDM6B indicate a complex relationship between the molecular biology of H3K27me3 removal and the cellular biology of cancer development. A clearer understanding of the factors regulating recruitment and activity of each of these enzymes within the Compass-like complex and to genes regulating distinct functions is needed to further understand the mechanistic basis of these observations.

\section{Alterations in the Substrate and Readers of Methylation of H3K27 and Alterations in DNA Methylation in Cancer}

In a set of landmark findings, genome sequencing efforts from two different groups, Schwartzentruber et al. [222] and Wu et al. [223], demonstrated a high frequency of mutations in H3F3A (>70\%, one of two genes encoding H3.3 [224]) converting lysine 27 to methionine (H3K27M) in pediatric high-grade glioma (pHGG) and that this mutation is an indicator of poor survival. Further studies from different laboratories extended the list of cancers known to carry mutations in $\mathrm{H} 3$ to include chondroblastoma, giant cell tumors in bone, chondrosarcoma, pediatric soft tissue sarcoma, 
head and neck squamous cell sarcoma, and leukemia [225-230]. Intriguingly, H3K27M mutations are not detected in other pediatric brain tumors such as medulloblastomas and ependymomas and rather seems to be specific for midline pHGGs [224,231].

Histone 3 has different variants, among which H3.3 is expressed constitutively [232-234]. These substitutions in the core histone protein dictate the binding specificity of the chaperone proteins, control their incorporation into and eviction from nucleosomes, thus contributing to differential localization of the H3 variants in the genome [235-238]. H3.3 is enriched at pericentromeric and telomeric regions and, importantly, at transcriptionally "active" or "poised" regions [239-241]. These H3.3-marked, poised, regions are also enriched for H3K4me3 or are bivalent: containing both H3K4me3 and H3K27me3. Therefore, deposition of any mutated histone protein can disrupt the homeostasis of bivalent domains [242]. In vitro evidence also suggests that H3K27M mutations act as a dominant negative inhibitor by disrupting PRC2 activity [236,243]. Bender et al. [236,243] and Chan et al. [244] established that mutant histones can disrupt the transcriptional program by 'trapping' the PRC2 complex, preventing deposition of the methyl mark on other PRC2 target regions, a process also linked to DNA hypomethylation. Funato and colleagues demonstrated that H3K27M synergizes with p53 loss and PDGFRA activation to induce DIPG (disuse intrinsic pontine glioma) [245]. Additionally, DNA methylation and H3.3K27M can work in concert to stabilize the tumor phenotype $[45,63,236,243,246-248]$.

Apart from the altered expression of or mutations in H3K27 writers (methyltransferases) and erasers (demethylases), alterations in readers and dysregulation of other chromatin regulators are also tied to H3K27me3 regulation. Epigenetic information, marked in histone structures, is decoded by these reader proteins, which can bind to chromatin marks using specific structures, such as chromodomains and PHD domains [249]. Alterations in the readers can mis-transduce the signal, thereby altering the functional outcome of the signal. The chromodomain of reader proteins recognizes lysine methylation marks in histones and other proteins. These proteins can recruit effector molecules and propagate and maintain a silent chromatin conformation with the help of WD40 domains [63]. Loss of heterozygosity for the chromodomain protein CDYL is found in cervical cancers and causes the de-repression of the proto-oncogene NTRK3, associated with poor prognosis [250]. Chromobox Homolog (CBX) proteins are responsible for recruiting the PRC1 complex at specific loci by recognizing H3K27me3 marks. CDYL binds H3K27me3 and recruits EZH2, bridging the PRC2 complex with already modified chromatin [251]. Loss of CBX7 expression is associated with invasiveness and EMT in many cancer types [252-254]. However, in leukemia, overexpression of CBX7 in hematopoietic stem progenitor cells enhances self-renewal, thus acting as an oncogene [255]. Mutation in EED seems to disrupt the formation of the PRC2 complex and abrogate the methyltransferase activity [256,257]. One rare mutation in the WD40 motif of EED can inhibit its interaction with H3K27me3, and therefore allow for the global H3K27me3 level to decrease $[63,258]$.

Many histone modifying enzymes can also indirectly impact H3K27me3, either at specific loci or genome wide. In cases of multiple myeloma (MM) bearing the $t(4 ; 14)$ translocation, MMSET is fused to the immunoglobin heavy chain locus, leading to its overexpression. Overexpression of MMSET causes a genome wide increase in abundance of H3K36me2 and a global reduction of H3K27me3 [259-261]. Nevertheless, Popovic et al. describe how, in melanoma, there are a few loci which are shielded from this MMSET overexpression and can exhibit a high level of H3K27me3 and thus repression of transcription of such specific loci [262]. A similar interplay was observed in B-cell ALL (B-ALL) and mantle cell lymphoma, where a recurrent mutation in SET domain of MMSET mimics the effects of MMSET overexpression [263,264]. In AML, there is a $\mathbf{t}(5 ; 11)$ translocation, which leads to fusion of MMSET homolog NSD1 and NUP98, resulting in loss of EZH2 and H3K27me3 at the HOXA locus [246].

Alterations in chromatin-remodeling complex proteins or other histone modifying proteins can also affect H3K27me3. Loss of SNF5, part of the SWI/SNF chromatin-remodeling complex, decreases polycomb protein displacement at specific loci, leading to an increase in EZH2 and H3K27me3 in T-cell lymphoma [142,265]. ARID1A of the SWI/SNF complex, is frequently mutated in many tumors. 
In ovarian clear cell carcinoma (OCCC) ARID1A mutation selectively suppresses cell proliferation by reducing H3K27me3 in selective loci $[143,266,267]$. HDACs (HDAC1 and HDAC3) interact with PRC2 and promote H3K27 methylation by removing the acetylation on $\mathrm{H} 3 \mathrm{~K} 27$, antagonizing the effect of $\mathrm{CBP} / \mathrm{p} 300$. HDAC expression is increased in various cancers and therefore impacts H3K27me3 levels [268-270].

Wilms' tumor 1 (WT1) is a transcription factor which can interact with DNA-demethylating enzymes. In about 10\% of AML cases, the WT1 gene harbors an inactivating mutation within its DNA-binding zinc finger domain, leading to an increase in DNA methylation. Hypermethylation then overlaps with genes targeted by PRC2 to increase H3K27me3, resulting in strong suppression [271-273]. An H3K4-specific KMT, KMT2 (KMT21), is frequently rearranged in AML along with a large number of other genes [274]. Although, due to fusions, KMT2 typically loses its KMT activity, it can still recruit coactivators of transcription and epigenetic modifiers, like EZH2, causing a disruption of the "bivalent" state [275]. It has been well established that monoubiquitinated H2AK119 (H2AK119ub1) can recruit the PRC2 complex to maintain chromatin repression [276,277]. In around $40 \%$ of breast cancer cases, TRIM37, a ubiquitin ligase for H2AK119ub1 is amplified resulting in higher recruitment of PRC2 and higher levels of H3K27me3 correlating with decreased survival of ER+ patients [63,277]. Overall, aberrations in readers, mutations in $\mathrm{H} 3$ itself, and other chromatin regulators of H3K27me3 can contribute outcomes as dramatic as ones caused by deregulation of chromatin writers and erasers.

Belying the common view that H3K27me3 is oncogenic, mutations of this residue within histone-coding genes have now been shown as oncogenic in some cancers. Nevertheless, reader proteins are either lost or over-expressed in multiple cancers further illustrating the context-specific interaction between $\mathrm{H} 3 \mathrm{~K} 27 \mathrm{me} 3$ and cancer.

Aberrant $5 \mathrm{mC}$ contributes to tumor progression and cancer-drug resistance, concepts reviewed recently by Göndör and colleagues [5]. In particular, a distinct subset of 5mC-driven cancers, termed $\mathrm{CpG}$ island methylator phenotypes (CIMPs), shows hypermethylation of a subset of CpG islands $[278,279]$. Later research made possible by the TCGA project identified CIMPs in colorectal, breast, and endometrial tumors as well as in glioblastomas and acute myeloid leukemias, but not in lung squamous, kidney renal cell cancers or serous ovarian cancers [280]. In cancers with global hypomethylation, however, the activity of PRC2 is expanded and contributes to gene silencing [281].

In glioblastoma multiforme (GBM) Parsons and Colleagues identified specific heterozygous somatic point mutations in the isocitrate dehydrogenase 1 (IDH1) most often in R132 [282]. In 2010, Noushmer and TCGA network colleagues showed an extremely tight correlation between IDH1R132H mutation and glioma CIMP (G-CIMP), although there were also a small number of WT IDH1 (IDH1WT) G-CIMP tumors [283,284]. According to TCGA database G-CIMP tumors are tightly associated with proneural subgroup. Further studies shown that introduction of IDH1R132H in cell lines with endogenous wild type IDH1 was sufficient to drive G-CIMP based DNA methylation events and increase the prevalence of H3K9me2, H3K27me3 and H3K36me3 [285,286]. These epigenomic changes mainly occur through changes of metabolic function of IDH proteins. Normally, IDH catalyzes the reduction of NADP+ (nicotinamide adenine dinucleotide phosphate) to NADPH by converting isocitrate to $\alpha$-ketoglutarate ( $\alpha-\mathrm{KG}$ ) [287]. However, mutant IDH catalyzes the conversion of $\alpha-\mathrm{KG}$ to D-2-hydroxyglutamate (2-HG) [288-292]. Since 2-HG inhibits both the Jumanji-C domain containing histone lysine demethylases and the TET family of enzymes [293,294], both pathways for removing methylation may be impacted.

\section{Cancer Cell Plasticity, EMT, and H3K27me3}

Cancer cell plasticity is a subversion of the conserved cellular processes that are signature features of embryonic development. It was traditionally thought that cellular differentiation and developmental options are restricted to a specific lineage fates in higher vertebrates, as opposed to "lower" vertebrates such as amphibians. However, recent experimental evidence indicates that mature mammalian cells are not as stable as was thought and can be induced to dedifferentiate or transdifferentiate. 
Investigators revealed importance of nuclear regulation to the "hidden plasticity" in differentiated cells by introducing one or more transcription factors [295-299]. In addition to its biological significance, such plasticity also makes possible the emergence of aberrant lineages when the epigenetic mechanisms maintaining cellular identity are subverted. Cancer is one of the possible outcomes of this aberrant reprogramming, whereupon the transcriptional and epigenetic states become disrupted, altering cellular lineages [300].

EMT or epithelial-mesenchymal transition, as its name implies, converts epithelial cells to mesenchymal cells by repressing the genes critical for epithelial states (e.g., E-cadherin, claudins) [301]. EMT can occur in response to normal physiologic signals, including hypoxia, extracellular matrix stiffness [302,303] and transforming growth factor $\beta$ (TGF $\beta$ ) [304,305], and is orchestrated by integrated networks of signal transduction pathways, transcription factors (Snail, Twist, Slug, FOXC2, and ZEB1/2 etc.) [306-309] and microRNAs [310-313]. EMT and its reverse process, mesenchymal-epithelial transition (MET), are important developmental reprogramming events that are nevertheless strongly implicated in tumor cell invasion and metastasis. In regard to epigenetic regulators, we now have an increased understanding of the roles of nucleosome remodeling complexes [314-316], DNA methylation, and de-methylation pathways [60,311], and histone-modification regulating enzymes [317-319].

Regulation of H3K27me3 is intimately involved in progression through EMT and MET. The PRC2 complex, by increasing H3K27me3 at target genes, leads to suppression of transcription. Thus, recruitment of PRC2 to the CDH1 gene, which encodes for E-cadherin, is one mechanism used by EMT transcription factors, in particular Snail1, to induce EMT in pancreatic, gastric, and breast cancer [320-323]. Using experimental models, expression of Twist was also shown to be sufficient for H3K27me3 accumulation at the CDH1 promoter [60]. Indeed, an elevated EMT signature, such as found in basal-like or BRCA-mutated breast cancers, correlates with overexpression of EZH2 [117,324-327]. While lacking enzymatic activity, overexpression of other PRC2 complex members, including BMI1 or EED, also correlates with EMT features and enhanced cancer progression [328-330].

Despite the clear association of EZH2 activity with EMT, the suppression of gene expression by H3K27me3 is not restricted to EMT-suppressed genes as EMT-promoting genes are also frequently silenced by H3K27me3. Indeed, in a model of EMT induced by Twist overexpression, a greater number of genes lose $\mathrm{H} 3 \mathrm{~K} 27 \mathrm{me} 3$ than gain this modification [60]. As a case in point, the ZEB1 locus is subject to silencing by $\mathrm{H} 3 \mathrm{~K} 27 \mathrm{me} 3$ in differentiated cancer cells and the modification is removed upon EMT-driven conversion into cancer stem cells [331].

Erasure of H3K27me3, through the activity of KDM6A or KDM6B, also impacts the EMT/MET status of individual cells. Just as both EMT-promoting and EMT-suppressing genes can be silenced by addition of H3K27me3, either set of genes (as well as bivalently modified genes [332]) can conversely be activated by removal of $\mathrm{H} 3 \mathrm{~K} 27 \mathrm{me} 3$. Illustrating the complexity of epigenetic regulation, KDM6B, like its enzymatic counterpart, EZH2 [333,334], is thought to promote EMT, an apparent paradox explored expertly in the recent review by Lachat et al. [335]. The likely "key" to unlocking this paradox lies in separating broad-based effects, due to changes in expression and activity of these enzymes, from the gene-specific effects driven by recruitment to precise enhancer and promoter regions. This was recently illustrated by Piexoto et al. who, using three models of EMT, used ELISA to demonstrate a general increase in H3K27me3 yet loss of the modification at specific ECM genes including ADAM19 and MMP9 [336].

On the other hand, KDM6A, while also possessing H3K27me3 activity is thought to prevent EMT and promote MET, partially through targeting CDH1 for activation [337-339]. We and others have shown that inhibition of the KDM6 family, through use of the small molecule GSK-J4, increases EMT and stemness features hinting at a dominant role of KDM6A over KDM6B in the governance of cellular states [339-341]. Yet, precisely how the two enzymes with identical activity drive disparate outcomes, for instance, by being recruited to distinct target genes, remains to be determined. In invasive breast cancer cell lines, depletion of KDM6A leads to an increase in Myc-dependent EMT factors including SNAI1 and ZEB1/2 [338]. The oxygen-dependent nature of KDM6A is also relevant in cell plasticity as 
hypoxia-induced loss of KDM6A function leads to suppression of DICER transcription and decreased expression of microRNAs that promote the epithelial state [342]. While these data point to clear mechanistic associations between KDM6A loss and cancer progression, other studies provide strong rationales for therapeutic inhibition of KDM6 proteins in cancer.

Concurrent action of both KDM6A and KDM6B is frequently associated with cell cycle in differentiated or cancer stem cells. In estrogen receptor (ER)-positive breast cancer, KDM6A protein is physically associated with ER and is necessary for the expression of hormone-response and proliferation-inducing genes. Indeed, in vivo administration of a dual KDM6- and LSD1-targeted inhibitor, MC3324, suppresses growth of ER-dependent breast cancers [343]. Conversely, KDM6 activity can also be associated with loss of proliferation as entrance of glioblastoma stem cells into a reversible, drug-tolerant, slow-cycling state is dependent on up-regulation and activity of KDM6A and KDM6, which can be prevented by GSK-J4, an inhibitor of both enzymes [344,345].

Considering the strong associations between EZH2, KDM6A, KDM6B and development, the link between these proteins and cancer cell plasticity will continue to become more apparent. Inhibitors of each of these enzymes are efficacious in altering the cancer cell differentiation state, sometimes toward stemness and sometimes toward differentiation, with associated effects on EMT/MET status and drug-resistance. To leverage this axis and improve cancer treatment will require both a better understanding of the intricacies of each molecular player and an improved set of molecular inhibitors, in order to inform carefully constructed pre-clinical experiments.

\section{Conclusions}

The human genome contains several thousand genes, each of which is regulated by proximal and distal elements that cooperate to induce expression of the coding sequences. Multi-genic regions are then organized into topologically associating domains and bordered by insulators which impact gene expression levels in a cell type-specific fashion [8,346-348]. Localization and compaction of these loci in the nucleus is a key determining factor for their activity $[78,349,350]$. Whereas certain stimuli block the differentiation program of cells by increasing the chromatin compactness, others can facilitate the permissive state, thereby inducing the cells' adaptive responses and can induce oncogenes.

We can conceptualize the permissive state of epigenetic interaction as lowering the height of the walls between canals in Waddington's landscape [8,351]. This permissive or "plastic" state allows cells to reroute to an alternative transcriptional state, using gene regulation for adaptive responses. When these altered transcriptional states propagate through cellular division, a new "clone" will arise and expand, as in oncogenic propagation. A large number of cancers show marked cell-to-cell variability in gene expression and functional phenotype [352]. Thus, we can hypothesize that epigenetic plasticity is one of the enabling factors that allow premalignant or malignant cells to adopt alternative pathways giving rise to epigenetic "adaptor-clones" that fuel tumor progression.

H3K27me3-regulating proteins are clearly involved in both cellular transformation and in cancer cell plasticity. Leveraging these findings into improved treatments will clearly require distinct plans depending on the tumor type and the predominance of either EZH2 or the KDM6 proteins in supporting tumor growth. An EZH2 inhibitor, tazemetostat, is currently in multiple early phase clinical trials for both solid tumors and lymphomas, in combination with other agents including immunotherapy and chemotherapy [22] (clinicaltrials.gov). Drug development of KDM6-specific inhibitors has not yet reached the level of clinical trial, in part due to the difficulty in achieving true specificity for the KDM6 family and avoiding other JmJC domain containing proteins [353]. Additional medicinal chemistry and drug discovery may facilitate testing of highly-specific inhibitors. Nevertheless, pre-clinical data supporting the applicability of targeting KDM6 proteins continue to emerge [192,354]. As highlighted above, cancer cell plasticity can drive tumor progression, in particular chemotherapy resistance, which can be dependent on epigenetic mechanisms including KDM6 activity [344]. Applying epigenetic-targeting molecules in the context of treatment resistance may enhance therapeutic efficacy in patients with tumor progression. 
Funding: Research support provided by Susan G. Komen, grant number CCR18548469.

Acknowledgments: The authors wish to thank members of the Taube Lab for informative discussions and editorial input. The results shown here are in whole or part based upon data generated by the TCGA Research Network: https://www.cancer.gov/tcga.

Conflicts of Interest: The funders had no role in the design of the study; in the collection, analyses, or interpretation of data; in the writing of the manuscript, or in the decision to publish the results.

\section{References}

1. Jambhekar, A.; Dhall, A.; Shi, Y. Roles and regulation of histone methylation in animal development. Nat. Rev. Mol. Cell Biol. 2020, 21, 59. [CrossRef] [PubMed]

2. Zhao, Y.; Garcia, B.A. Comprehensive Catalog of Currently Documented Histone Modifications. Cold Spring Harb. Perspect. Biol. 2015, 7, a025064. [CrossRef]

3. Baylin, B.S.; Jones, P.A. A decade of exploring the cancer epigenome-biological and translational implications. Nat. Rev. Cancer 2011, 11, 726-734. [CrossRef]

4. Esteller, M. Epigenetics in cancer. N. Engl. J. Med. 2008, 358, 1148-1159. [CrossRef]

5. Feinberg, P.A.; Koldobskiy, M.A.; Gondor, A. Epigenetic modulators, modifiers and mediators in cancer aetiology and progression. Nat. Rev. Genet. 2016, 17, 284-299. [CrossRef] [PubMed]

6. Shen, H.; Laird, P.W. Interplay between the cancer genome and epigenome. Cell 2013, 153, 38-55. [CrossRef] [PubMed]

7. You, S.J.; Jones, P.A. Cancer genetics and epigenetics: Two sides of the same coin? Cancer Cell 2012, 22, 9-20. [CrossRef] [PubMed]

8. Flavahan, A.W.; Gaskell, E.; Bernstein, B.E. Epigenetic plasticity and the hallmarks of cancer. Science 2017, 357, 6348. [CrossRef]

9. Hanahan, D.; Weinberg, R.A. The hallmarks of cancer. Cell 2000, 100, 57-70. [CrossRef]

10. Hanahan, D.; Weinberg, R.A. Hallmarks of cancer: The next generation. Cell 2011, 144, 646-674. [CrossRef]

11. Sharma, S.; Kelly, T.K.; Jones, P.A. Epigenetics in cancer. Carcinogenesis 2010, 31, 27-36. [CrossRef] [PubMed]

12. Kouzarides, T. Chromatin modifications and their function. Cell 2007, 128, 693-705. [CrossRef] [PubMed]

13. Bennett, L.R.; Licht, J.D. Targeting Epigenetics in Cancer. Annu. Rev. Pharmacol. Toxicol. 2018, 58, 187-207. [CrossRef] [PubMed]

14. Biswas, S.; Rao, C.M. Epigenetic tools (The Writers, The Readers and The Erasers) and their implications in cancer therapy. Eur. J. Pharmacol. 2018, 837, 8-24. [CrossRef]

15. Barski, A.; Cuddapah, S.; Cui, K.; Roh, T.Y.; Schones, D.E.; Wang, Z.; Wei, G.; Chepelev, I.; Zhao, K. High-resolution profiling of histone methylations in the human genome. Cell 2007, 129, 823-837. [CrossRef]

16. Kimura, H. Histone modifications for human epigenome analysis. J. Hum. Genet. 2013, 58, 439-445. [CrossRef]

17. Heintzman, N.D.; Hon, G.C.; Hawkins, R.D.; Kheradpour, P.; Stark, A.; Harp, L.F.; Ye, Z.; Lee, L.K.; Stuart, R.K.; Ching, C.W.; et al. Histone modifications at human enhancers reflect global cell-type-specific gene expression. Nature 2009, 459, 108-112. [CrossRef]

18. Haupt, Y.; Alexander, W.S.; Barri, G.; Klinken, S.P.; Adams, J.M. Novel zinc finger gene implicated as myc collaborator by retrovirally accelerated lymphomagenesis in E mu-myc transgenic mice. Cell 1991, 65, 753-763. [CrossRef]

19. Raaphorst, F.M.; van Kemenade, F.J.; Blokzijl, T.; Fieret, E.; Hamer, K.M.; Satijn, D.P.; Otte, A.P.; Meijer, C.J. Coexpression of BMI-1 and EZH2 polycomb group genes in Reed-Sternberg cells of Hodgkin's disease. Am. J. Pathol. 2000, 157, 709-715. [CrossRef]

20. van Lohuizen, M.; Verbeek, S.; Scheijen, B.; Wientjens, E.; van der Gulden, H.; Berns, A. Identification of cooperating oncogenes in E mu-myc transgenic mice by provirus tagging. Cell 1991, 65, 737-752. [CrossRef]

21. Laugesen, A.; Højfeldt, J.W.; Helin, K. Molecular Mechanisms Directing PRC2 Recruitment and H3K27 Methylation. Mol. Cell 2019, 74, 8-18. [CrossRef] [PubMed]

22. Kim, H.K.; Roberts, C.W. Targeting EZH2 in cancer. Nat. Med. 2016, 22, 128-134. [CrossRef] [PubMed]

23. Völkel, P.; Dupret, B.; Le Bourhis, X.; Angrand, P.O. Diverse involvement of EZH2 in cancer epigenetics. Am. J. Transl. Res. 2015, 7, 175-193. 
24. Nekrasov, M.; Klymenko, T.; Fraterman, S.; Papp, B.; Oktaba, K.; Köcher, T.; Cohen, A.; Stunnenberg, H.G.; Wilm, M.; Müller, J. Pcl-PRC2 is needed to generate high levels of H3-K27 trimethylation at Polycomb target genes. Embo. J. 2007, 26, 4078-4088. [CrossRef] [PubMed]

25. Cao, R.; Zhang, Y. SUZ12 is required for both the histone methyltransferase activity and the silencing function of the EED-EZH2 complex. Mol. Cell 2004, 15, 57-67. [CrossRef] [PubMed]

26. Chu, C.S.; Lo, P.W.; Yeh, Y.H.; Hsu, P.H.; Peng, S.H.; Teng, Y.C.; Kang, M.L.; Wong, C.H.; Juan, L.J. O-GlcNAcylation regulates EZH2 protein stability and function. Proc. Natl. Acad. Sci. USA 2014, 111, 1355-1360. [CrossRef]

27. Margueron, R.; Li, G.; Sarma, K.; Blais, A.; Zavadil, J.; Woodcock, C.L.; Dynlacht, B.D.; Reinberg, D. Ezh1 and Ezh2 maintain repressive chromatin through different mechanisms. Mol. Cell 2008, 32, 503-518. [CrossRef]

28. Wang, H.; Wang, L.; Erdjument-Bromage, H.; Vidal, M.; Tempst, P.; Jones, R.S.; Zhang, Y. Role of histone H2A ubiquitination in Polycomb silencing. Nature 2004, 431, 873-878. [CrossRef]

29. Stock, J.K.; Giadrossi, S.; Casanova, M.; Brookes, E.; Vidal, M.; Koseki, H.; Brockdorff, N.; Fisher, A.G.; Pombo, A. Ring1-mediated ubiquitination of H2A restrains poised RNA polymerase II at bivalent genes in mouse ES cells. Nat. Cell Biol. 2007, 9, 1428-1435. [CrossRef]

30. Klose, J.R.; Zhang, Y. Regulation of histone methylation by demethylimination and demethylation. Nat. Rev. Mol. Cell Biol. 2007, 8, 307-318. [CrossRef]

31. Shi, Y. Histone lysine demethylases: Emerging roles in development, physiology and disease. Nat. Rev. Genet. 2007, 8, 829-833. [CrossRef] [PubMed]

32. Cloos, P.A.; Christensen, J.; Agger, K.; Helin, K. Erasing the methyl mark: Histone demethylases at the center of cellular differentiation and disease. Genes Dev. 2008, 22, 1115-1140. [CrossRef] [PubMed]

33. Yokoyama, A.; Cleary, M.L. Menin critically links MLL proteins with LEDGF on cancer-associated target genes. Cancer Cell 2008, 14, 36-46. [CrossRef] [PubMed]

34. Canovas, S.; Cibelli, J.B.; Ross, P.J. Jumonji domain-containing protein 3 regulates histone 3 lysine 27 methylation during bovine preimplantation development. Proc. Natl. Acad. Sci. USA 2012, 109, $2400-2405$. [CrossRef]

35. Paik, K.W.; Paik, D.C.; Kim, S. Historical review: The field of protein methylation. Trends Biochem. Sci. 2007, 32, 146-152. [CrossRef]

36. Arifuzzaman, S.; Khatun, M.R.; Khatun, R. Emerging of lysine demethylases (KDMs): From pathophysiological insights to novel therapeutic opportunities. Biomed. Pharmacother. 2020, 129, 110392. [CrossRef]

37. Klose, J.R.; Kallin, E.M.; Zhang, Y. JmjC-domain-containing proteins and histone demethylation. Nat. Rev. Genet. 2006, 7, 715-727. [CrossRef]

38. Klose, R.J.; Yamane, K.; Bae, Y.; Zhang, D.; Erdjument-Bromage, H.; Tempst, P.; Wong, J.; Zhang, Y. The transcriptional repressor JHDM3A demethylates trimethyl histone H3 lysine 9 and lysine 36. Nature 2006, 442, 312-316. [CrossRef]

39. Shi, Y.; Lan, F.; Matson, C.; Mulligan, P.; Whetstine, J.R.; Cole, P.A.; Casero, R.A.; Shi, Y. Histone demethylation mediated by the nuclear amine oxidase homolog LSD1. Cell 2004, 119, 941-953. [CrossRef]

40. Tsukada, Y.-I.; Fang, J.; Erdjument-Bromage, H.; Warren, M.E.; Borchers, C.H.; Tempst, P.; Zhang, Y. Histone demethylation by a family of JmjC domain-containing proteins. Nature 2006, 439, 811-816. [CrossRef]

41. Kooistra, M.S.; Helin, K. Molecular mechanisms and potential functions of histone demethylases. Nat. Rev. Mol. Cell Biol. 2012, 13, 297-311. [CrossRef] [PubMed]

42. Dimitrova, E.; Turberfield, A.H.; Klose, R.J. Histone demethylases in chromatin biology and beyond. EMBO Rep. 2015, 16, 1620-1639. [CrossRef] [PubMed]

43. Johansson, C.; Tumber, A.; Che, K.; Cain, P.; Nowak, R.; Gileadi, C.; Oppermann, U. The roles of Jumonji-type oxygenases in human disease. Epigenomics 2014, 6, 89-120. [CrossRef] [PubMed]

44. Pedersen, T.M.; Helin, K. Histone demethylases in development and disease. Trends Cell Biol. 2010, 20, 662-671. [CrossRef] [PubMed]

45. Brinkman, A.B.; Gu, H.; Bartels, S.J.; Zhang, Y.; Matarese, F.; Simmer, F.; Marks, H.; Bock, C.; Gnirke, A.; Meissner, A.; et al. Sequential ChIP-bisulfite sequencing enables direct genome-scale investigation of chromatin and DNA methylation cross-talk. Genome Res. 2012, 22, 1128-1138. [CrossRef]

46. Wu, H.; Coskun, V.; Tao, J.; Xie, W.; Ge, W.; Yoshikawa, K.; Li, E.; Zhang, Y.; Sun, Y.E. Dnmt3a-dependent nonpromoter DNA methylation facilitates transcription of neurogenic genes. Science 2010, 329, $444-448$. [CrossRef] 
47. Statham, A.L.; Robinson, M.D.; Song, J.Z.; Coolen, M.W.; Stirzaker, C.; Clark, S.J. Bisulfite sequencing of chromatin immunoprecipitated DNA (BisChIP-seq) directly informs methylation status of histone-modified DNA. Genome Res. 2012, 22, 1120-1127. [CrossRef]

48. Wu, X.; Zhang, Y. TET-mediated active DNA demethylation: Mechanism, function and beyond. Nat. Rev. Genet. 2017, 18, 517-534. [CrossRef]

49. Lee, W.; Kim, J.; Yun, J.M.; Ohn, T.; Gong, Q. MeCP2 regulates gene expression through recognition of H3K27me3. Nat. Commun. 2020, 11, 3140. [CrossRef]

50. O'Carroll, D.; Erhardt, S.; Pagani, M.; Barton, S.C.; Surani, M.A.; Jenuwein, T. The Polycomb-Group GeneEzh2 Is Required for Early Mouse Development. Mol. Cell. Biol. 2001, 21, 4330-4336. [CrossRef]

51. Schumacher, A.; Faust, C.; Magnuson, T. Positional cloning of a global regulator of anterior-posterior patterning in mice. Nature 1996, 384, 648. [CrossRef] [PubMed]

52. Pasini, D.; Bracken, A.P.; Jensen, M.R.; Lazzerini Denchi, E.; Helin, K. Suz12 is essential for mouse development and for EZH2 histone methyltransferase activity. Embo. J. 2004, 23, 4061-4071. [CrossRef] [PubMed]

53. Laugesen, A.; Højfeldt, J.W.; Helin, K. Role of the Polycomb Repressive Complex 2 (PRC2) in Transcriptional Regulation and Cancer. Cold Spring Harb. Perspect. Med. 2016, 6, a026575. [CrossRef] [PubMed]

54. Laugesen, A.; Helin, K. Chromatin repressive complexes in stem cells, development, and cancer. Cell Stem Cell 2014, 14, 735-751. [CrossRef]

55. Liu, J.; An, L.; Wang, J.; Liu, Z.; Dai, Y.; Liu, Y.; Yang, L.; Du, F. Dynamic patterns of H3K4me3, H3K27me3, and Nanog during rabbit embryo development. Am. J. Transl. Res. 2019, 11, 430-441.

56. Liu, X.; Wang, C.; Liu, W.; Li, J.; Li, C.; Kou, X.; Chen, J.; Zhao, Y.; Gao, H.; Wang, H.; et al. Distinct features of H3K4me3 and H3K27me3 chromatin domains in pre-implantation embryos. Nature 2016, 537, 558-562. [CrossRef]

57. Zhang, B.; Zheng, H.; Huang, B.; Li, W.; Xiang, Y.; Peng, X.; Ming, J.; Wu, X.; Zhang, Y.; Xu, Q.; et al. Allelic reprogramming of the histone modification $\mathrm{H} 3 \mathrm{~K} 4 \mathrm{me} 3$ in early mammalian development. Nature 2016, 537, 553-557. [CrossRef]

58. Zheng, H.; Huang, B.; Zhang, B.; Xiang, Y.; Du, Z.; Xu, Q.; Li, Y.; Wang, Q.; Ma, J.; Peng, X.; et al. Resetting Epigenetic Memory by Reprogramming of Histone Modifications in Mammals. Mol. Cell. 2016, 63, 1066-1079. [CrossRef]

59. Mikkelsen, T.S.; Ku, M.; Jaffe, D.B.; Issac, B.; Lieberman, E.; Giannoukos, G.; Alvarez, P.; Brockman, W.; Kim, T.K.; Koche, R.P.; et al. Genome-wide maps of chromatin state in pluripotent and lineage-committed cells. Nature 2007, 448, 553-560. [CrossRef]

60. Malouf, G.G.; Taube, J.H.; Lu, Y.; Roysarkar, T.; Panjarian, S.; Estecio, M.R.; Jelinek, J.; Yamazaki, J.; Raynal, N.J.; Long, H.; et al. Architecture of epigenetic reprogramming following Twist1-mediated epithelial-mesenchymal transition. Genome Biol. 2013, 14, R144. [CrossRef]

61. Van der Meulen, J.; Speleman, F.; Van Vlierberghe, P. The H3K27me3 demethylase UTX in normal development and disease. Epigenetics 2014, 9, 658-668. [CrossRef] [PubMed]

62. Schuettengruber, B.; Chourrout, D.; Vervoort, M.; Leblanc, B.; Cavalli, G. Genome regulation by polycomb and trithorax proteins. Cell 2007, 128, 735-745. [CrossRef] [PubMed]

63. Nichol, J.N.; Dupere-Richer, D.; Ezponda, T.; Licht, J.D.; Miller, W.H., Jr. H3K27 Methylation: A Focal Point of Epigenetic Deregulation in Cancer. Adv. Cancer Res. 2016, 131, 59-95. [PubMed]

64. Bracken, A.P.; Pasini, D.; Capra, M.; Prosperini, E.; Colli, E.; Helin, K. EZH2 is downstream of the pRB-E2F pathway, essential for proliferation and amplified in cancer. EMBO J. 2003, 22, 5323-5335. [CrossRef]

65. Friedman, J.M.; Liang, G.; Liu, C.C.; Wolff, E.M.; Tsai, Y.C.; Ye, W.; Zhou, X.; Jones, P.A. The putative tumor suppressor microRNA-101 modulates the cancer epigenome by repressing the polycomb group protein EZH2. Cancer Res. 2009, 69, 2623-2629. [CrossRef]

66. Saramaki, O.R.; Tammela, T.L.; Martikainen, P.M.; Vessella, R.L.; Visakorpi, T. The gene for polycomb group protein enhancer of zeste homolog 2 (EZH2) is amplified in late-stage prostate cancer. Genes Chromosomes Cancer 2006, 45, 639-645. [CrossRef]

67. Wainwright, N.E.; Scaffidi, P. Epigenetics and Cancer Stem Cells: Unleashing, Hijacking, and Restricting Cellular Plasticity. Trends Cancer 2017, 3, 372-386. [CrossRef]

68. Crea, F.; Paolicchi, E.; Marquez, V.E.; Danesi, R. Polycomb genes and cancer: Time for clinical application? Crit. Rev. Oncol. Hematol. 2012, 83, 184-193. [CrossRef] 
69. Bachmann, I.M.; Halvorsen, O.J.; Collett, K.; Stefansson, I.M.; Straume, O.; Haukaas, S.A.; Salvesen, H.B.; Otte, A.P.; Akslen, L.A. EZH2 expression is associated with high proliferation rate and aggressive tumor subgroups in cutaneous melanoma and cancers of the endometrium, prostate, and breast. J. Clin. Oncol. 2006, 24, 268-273. [CrossRef]

70. Hinz, S.; Kempkensteffen, C.; Christoph, F.; Hoffmann, M.; Krause, H.; Schrader, M.; Schostak, M.; Miller, K.; Weikert, S. Expression of the polycomb group protein EZH2 and its relation to outcome in patients with urothelial carcinoma of the bladder. J. Cancer Res. Clin. Oncol. 2008, 134, 331-336. [CrossRef]

71. Wang, H.; Albadine, R.; Magheli, A.; Guzzo, T.J.; Ball, M.W.; Hinz, S.; Schoenberg, M.P.; Netto, G.J.; Gonzalgo, M.L. Increased EZH2 protein expression is associated with invasive urothelial carcinoma of the bladder. Urol. Oncol. 2012, 30, 428-433. [CrossRef] [PubMed]

72. Rao, Z.Y.; Cai, M.Y.; Yang, G.F.; He, L.R.; Mai, S.J.; Hua, W.F.; Liao, Y.J.; Deng, H.X.; Chen, Y.C.; Guan, X.Y.; et al. EZH2 supports ovarian carcinoma cell invasion and/or metastasis via regulation of TGF-beta1 and is a predictor of outcome in ovarian carcinoma patients. Carcinogenesis 2010, 31, 1576-1583. [CrossRef] [PubMed]

73. Lee, W.H.; Choe, M. Expression of EZH2 in renal cell carcinoma as a novel prognostic marker. Pathol. Int. 2012, 62, 735-741. [CrossRef]

74. Tong, Z.T.; Cai, M.Y.; Wang, X.G.; Kong, L.L.; Mai, S.J.; Liu, Y.H.; Zhang, H.B.; Liao, Y.J.; Zheng, F.; Zhu, W.; et al. EZH2 supports nasopharyngeal carcinoma cell aggressiveness by forming a co-repressor complex with HDAC1/HDAC2 and Snail to inhibit E-cadherin. Oncogene 2012, 31, 583-594. [CrossRef] [PubMed]

75. Smits, M.; Nilsson, J.; Mir, S.E.; van der Stoop, P.M.; Hulleman, E.; Niers, J.M.; de Witt Hamer, P.C.; Marquez, V.E.; Cloos, J.; Krichevsky, A.M.; et al. miR-101 is down-regulated in glioblastoma resulting in EZH2-induced proliferation, migration, and angiogenesis. Oncotarget 2010, 1, 710-720. [CrossRef] [PubMed]

76. McHugh, J.B.; Fullen, D.R.; Ma, L.; Kleer, C.G.; Su, L.D. Expression of polycomb group protein EZH2 in nevi and melanoma. J. Cutan. Pathol. 2007, 34, 597-600. [CrossRef]

77. Li, X.; Gonzalez, M.E.; Toy, K.; Filzen, T.; Merajver, S.D.; Kleer, C.G. Targeted overexpression of EZH2 in the mammary gland disrupts ductal morphogenesis and causes epithelial hyperplasia. Am. J. Pathol. 2009, 175, 1246-1254. [CrossRef]

78. Comet, I.; Riising, E.M.; Leblanc, B.; Helin, K. Maintaining cell identity: PRC2-mediated regulation of transcription and cancer. Nat. Rev. Cancer 2016, 16, 803-810. [CrossRef]

79. Cerami, E.; Gao, J.; Dogrusoz, U.; Gross, B.E.; Sumer, S.O.; Aksoy, B.A.; Jacobsen, A.; Byrne, C.J.; Heuer, M.L.; Larsson, E.; et al. The cBio Cancer Genomics Portal: An Open Platform for Exploring Multidimensional Cancer Genomics Data. Cancer Discov. 2012, 2, 401-404. [CrossRef]

80. Gao, J.; Aksoy, B.A.; Dogrusoz, U.; Dresdner, G.; Gross, B.; Sumer, S.O.; Sun, Y.; Jacobsen, A.; Sinha, R.; Larsson, E.; et al. Integrative analysis of complex cancer genomics and clinical profiles using the cBioPortal. Sci. Signal. 2013, 6, pl1. [CrossRef]

81. Varambally, S.; Yu, J.; Laxman, B.; Rhodes, D.R.; Mehra, R.; Tomlins, S.A.; Shah, R.B.; Chandran, U.; Monzon, F.A.; Becich, M.J.; et al. Integrative genomic and proteomic analysis of prostate cancer reveals signatures of metastatic progression. Cancer Cell 2005, 8, 393-406. [CrossRef] [PubMed]

82. Curtis, C.; Shah, S.P.; Chin, S.F.; Turashvili, G.; Rueda, O.M.; Dunning, M.J.; Speed, D.; Lynch, A.G.; Samarajiwa, S.; Yuan, Y.; et al. The genomic and transcriptomic architecture of 2,000 breast tumours reveals novel subgroups. Nature 2012, 486, 346-352. [CrossRef] [PubMed]

83. Ki, D.H.; Jeung, H.C.; Park, C.H.; Kang, S.H.; Lee, G.Y.; Lee, W.S.; Kim, N.K.; Chung, H.C.; Rha, S.Y. Whole genome analysis for liver metastasis gene signatures in colorectal cancer. Int. J. Cancer 2007, 121, 2005-2012. [CrossRef] [PubMed]

84. Hong, Y.; Downey, T.; Eu, K.W.; Koh, P.K.; Cheah, P.Y. A 'metastasis-prone' signature for early-stage mismatch-repair proficient sporadic colorectal cancer patients and its implications for possible therapeutics. Clin. Exp. Metastasis 2010, 27, 83-90. [CrossRef]

85. Roessler, S.; Jia, H.L.; Budhu, A.; Forgues, M.; Ye, Q.H.; Lee, J.S.; Thorgeirsson, S.S.; Sun, Z.; Tang, Z.Y.; Qin, L.X.; et al. A unique metastasis gene signature enables prediction of tumor relapse in early-stage hepatocellular carcinoma patients. Cancer Res. 2010, 70, 10202-10212. [CrossRef]

86. Beroukhim, R.; Brunet, J.P.; Di Napoli, A.; Mertz, K.D.; Seeley, A.; Pires, M.M.; Linhart, D.; Worrell, R.A.; Moch, H.; Rubin, M.A.; et al. Patterns of gene expression and copy-number alterations in von-hippel lindau disease-associated and sporadic clear cell carcinoma of the kidney. Cancer Res. 2009, 69, 4674-4681. [CrossRef] 
87. Yoshihara, K.; Tajima, A.; Komata, D.; Yamamoto, T.; Kodama, S.; Fujiwara, H.; Suzuki, M.; Onishi, Y.; Hatae, M.; Sueyoshi, K.; et al. Gene expression profiling of advanced-stage serous ovarian cancers distinguishes novel subclasses and implicates ZEB2 in tumor progression and prognosis. Cancer Sci. 2009, 100, 1421-1428. [CrossRef]

88. Detwiller, K.Y.; Fernando, N.T.; Segal, N.H.; Ryeom, S.W.; D'Amore, P.A.; Yoon, S.S. Analysis of hypoxia-related gene expression in sarcomas and effect of hypoxia on RNA interference of vascular endothelial cell growth factor A. Cancer Res. 2005, 65, 5881-5889. [CrossRef]

89. Barretina, J.; Taylor, B.S.; Banerji, S.; Ramos, A.H.; Lagos-Quintana, M.; Decarolis, P.L.; Shah, K.; Socci, N.D.; Weir, B.A.; Ho, A.; et al. Subtype-specific genomic alterations define new targets for soft-tissue sarcoma therapy. Nat. Genet. 2010, 42, 715-721. [CrossRef]

90. Zhai, Y.; Kuick, R.; Nan, B.; Ota, I.; Weiss, S.J.; Trimble, C.L.; Fearon, E.R.; Cho, K.R. Gene expression analysis of preinvasive and invasive cervical squamous cell carcinomas identifies HOXC10 as a key mediator of invasion. Cancer Res. 2007, 67, 10163-10172. [CrossRef]

91. Scotto, L.; Narayan, G.; Nandula, S.V.; Subramaniyam, S.; Kaufmann, A.M.; Wright, J.D.; Pothuri, B.; Mansukhani, M.; Schneider, A.; Arias-Pulido, H.; et al. Integrative genomics analysis of chromosome $5 \mathrm{p}$ gain in cervical cancer reveals target over-expressed genes, including Drosha. Mol. Cancer 2008, 7, 58. [CrossRef] [PubMed]

92. Scotto, L.; Narayan, G.; Nandula, S.V.; Arias-Pulido, H.; Subramaniyam, S.; Schneider, A.; Kaufmann, A.M.; Wright, J.D.; Pothuri, B.; Mansukhani, M.; et al. Identification of copy number gain and overexpressed genes on chromosome arm $20 \mathrm{q}$ by an integrative genomic approach in cervical cancer: Potential role in progression. Genes Chromosomes Cancer 2008, 47, 755-765. [CrossRef] [PubMed]

93. Su, L.J.; Chang, C.W.; Wu, Y.C.; Chen, K.C.; Lin, C.J.; Liang, S.C.; Lin, C.H.; Whang-Peng, J.; Hsu, S.L.; Chen, C.H.; et al. Selection of DDX5 as a novel internal control for Q-RT-PCR from microarray data using a block bootstrap re-sampling scheme. BMC Genomics 2007, 8, 140. [CrossRef] [PubMed]

94. Lee, J.; Kotliarova, S.; Kotliarov, Y.; Li, A.; Su, Q.; Donin, N.M.; Pastorino, S.; Purow, B.W.; Christopher, N.; Zhang, W.; et al. Tumor stem cells derived from glioblastomas cultured in bFGF and EGF more closely mirror the phenotype and genotype of primary tumors than do serum-cultured cell lines. Cancer Cell 2006, 9, 391-403. [CrossRef] [PubMed]

95. Kamminga, L.M.; Bystrykh, L.V.; de Boer, A.; Houwer, S.; Douma, J.; Weersing, E.; Dontje, B.; de Haan, G. The Polycomb group gene Ezh2 prevents hematopoietic stem cell exhaustion. Blood 2006, 107, 2170-2179. [CrossRef] [PubMed]

96. Haslinger, C.; Schweifer, N.; Stilgenbauer, S.; Döhner, H.; Lichter, P.; Kraut, N.; Stratowa, C.; Abseher, R. Microarray gene expression profiling of B-cell chronic lymphocytic leukemia subgroups defined by genomic aberrations and VH mutation status. J. Clin. Oncol. 2004, 22, 3937-3949. [CrossRef]

97. Basso, K.; Margolin, A.A.; Stolovitzky, G.; Klein, U.; Dalla-Favera, R.; Califano, A. Reverse engineering of regulatory networks in human B cells. Nat. Genet. 2005, 37, 382-390. [CrossRef]

98. Haferlach, T.; Kohlmann, A.; Wieczorek, L.; Basso, G.; Kronnie, G.T.; Béné, M.C.; De Vos, J.; Hernández, J.M.; Hofmann, W.K.; Mills, K.I.; et al. Clinical utility of microarray-based gene expression profiling in the diagnosis and subclassification of leukemia: Report from the International Microarray Innovations in Leukemia Study Group. J. Clin. Oncol. 2010, 28, 2529-2537. [CrossRef]

99. Sanchez-Carbayo, M.; Socci, N.D.; Lozano, J.; Saint, F.; Cordon-Cardo, C. Defining molecular profiles of poor outcome in patients with invasive bladder cancer using oligonucleotide microarrays. J. Clin. Oncol. 2006, 24, 778-789. [CrossRef]

100. Giordano, T.J.; Thomas, D.G.; Kuick, R.; Lizyness, M.; Misek, D.E.; Smith, A.L.; Sanders, D.; Aljundi, R.T.; Gauger, P.G.; Thompson, N.W.; et al. Distinct transcriptional profiles of adrenocortical tumors uncovered by DNA microarray analysis. Am. J. Pathol. 2003, 162, 521-531. [CrossRef]

101. Hu, N.; Clifford, R.J.; Yang, H.H.; Wang, C.; Goldstein, A.M.; Ding, T.; Taylor, P.R.; Lee, M.P. Genome wide analysis of DNA copy number neutral loss of heterozygosity (CNNLOH) and its relation to gene expression in esophageal squamous cell carcinoma. BMC Genomics 2010, 11, 576. [CrossRef] [PubMed]

102. Bugler, J.; Kinstrie, R.; Scott, M.T.; Vetrie, D. Epigenetic Reprogramming and Emerging Epigenetic Therapies in CML. Front. Cell Dev. Biol. 2019, 7, 136. [CrossRef] [PubMed]

103. Lund, K.; Adams, P.D.; Copland, M. EZH2 in normal and malignant hematopoiesis. Front. Cell Dev. Biol. 2019, 7, 136. [CrossRef] [PubMed] 
104. Morin, R.D.; Johnson, N.A.; Severson, T.M.; Mungall, A.J.; An, J.; Goya, R.; Paul, J.E.; Boyle, M.; Woolcock, B.W.; Kuchenbauer, F.; et al. Somatic mutations altering EZH2 (Tyr641) in follicular and diffuse large B-cell lymphomas of germinal-center origin. Nat. Genet. 2010, 42, 181-185. [CrossRef] [PubMed]

105. Sasaki, D.; Imaizumi, Y.; Hasegawa, H.; Osaka, A.; Tsukasaki, K.; Choi, Y.L.; Mano, H.; Marquez, V.E.; Hayashi, T.; Yanagihara, K.; et al. Overexpression of Enhancer of zeste homolog 2 with trimethylation of lysine 27 on histone $\mathrm{H} 3$ in adult T-cell leukemia/lymphoma as a target for epigenetic therapy. Haematologica 2011, 96, 712-719. [CrossRef]

106. Beguelin, W.; Popovic, R.; Teater, M.; Jiang, Y.; Bunting, K.L.; Rosen, M.; Shen, H.; Yang, S.N.; Wang, L.; Ezponda, T.; et al. EZH2 is required for germinal center formation and somatic EZH2 mutations promote lymphoid transformation. Cancer Cell 2013, 23, 677-692. [CrossRef]

107. Herrera-Merchan, A.; Arranz, L.; Ligos, J.M.; de Molina, A.; Dominguez, O.; Gonzalez, S. Ectopic expression of the histone methyltransferase Ezh2 in haematopoietic stem cells causes myeloproliferative disease. Nat. Commun. 2012, 3, 623. [CrossRef]

108. Mousavi, K.; Zare, H.; Wang, A.H.; Sartorelli, V. Polycomb Protein Ezh1 Promotes RNA Polymerase II Elongation. Mol. Cell 2012, 45, 255-262. [CrossRef]

109. Xu, F.; Li, X.; Wu, L.; Zhang, Q.; Yang, R.; Yang, Y.; Zhang, Z.; He, Q.; Chang, C. Overexpression of the EZH2, RING1 and BMI1 genes is common in myelodysplastic syndromes: Relation to adverse epigenetic alteration and poor prognostic scoring. Ann. Hematol. 2011, 90, 643-653. [CrossRef]

110. Grubach, L.; Juhl-Christensen, C.; Rethmeier, A.; Olesen, L.H.; Aggerholm, A.; Hokland, P.; Østergaard, M. Gene expression profiling of Polycomb, Hox and Meis genes in patients with acute myeloid leukaemia. Eur. J. Haematol. 2008, 81, 112-122. [CrossRef]

111. Fujii, S.; Tokita, K.; Wada, N.; Ito, K.; Yamauchi, C.; Ito, Y.; Ochiai, A. MEK-ERK pathway regulates EZH2 overexpression in association with aggressive breast cancer subtypes. Oncogene 2011, 30, 4118-4128. [CrossRef] [PubMed]

112. Coe, B.P.; Thu, K.L.; Aviel-Ronen, S.; Vucic, E.A.; Gazdar, A.F.; Lam, S.; Tsao, M.S.; Lam, W.L. Genomic deregulation of the $\mathrm{E} 2 \mathrm{~F} / \mathrm{Rb}$ pathway leads to activation of the oncogene $\mathrm{EZH} 2$ in small cell lung cancer. PLOS ONE 2013, 8, e71670. [CrossRef]

113. Koh, C.M.; Iwata, T.; Zheng, Q.; Bethel, C.; Yegnasubramanian, S.; De Marzo, A.M. Myc enforces overexpression of EZH2 in early prostatic neoplasia via transcriptional and post-transcriptional mechanisms. Oncotarget 2011, 2, 669-683. [CrossRef] [PubMed]

114. Kunderfranco, P.; Mello-Grand, M.; Cangemi, R.; Pellini, S.; Mensah, A.; Albertini, V.; Malek, A.; Chiorino, G.; Catapano, C.V.; Carbone, G.M. ETS transcription factors control transcription of EZH2 and epigenetic silencing of the tumor suppressor gene Nkx3.1 in prostate cancer. PLoS ONE 2010, 5, e10547. [CrossRef] [PubMed]

115. Garipov, A.; Li, H.; Bitler, B.G.; Thapa, R.J.; Balachandran, S.; Zhang, R. NF-YA underlies EZH2 upregulation and is essential for proliferation of human epithelial ovarian cancer cells. Mol. Cancer Res. 2013, 11, 360-369. [CrossRef] [PubMed]

116. Kalashnikova, E.V.; Revenko, A.S.; Gemo, A.T.; Andrews, N.P.; Tepper, C.G.; Zou, J.X.; Cardiff, R.D.; Borowsky, A.D.; Chen, H.W. ANCCA/ATAD2 overexpression identifies breast cancer patients with poor prognosis, acting to drive proliferation and survival of triple-negative cells through control of B-Myb and EZH2. Cancer Res. 2010, 70, 9402-9412. [CrossRef]

117. Chang, C.J.; Yang, J.Y.; Xia, W.; Chen, C.T.; Xie, X.; Chao, C.H.; Woodward, W.A.; Hsu, J.M.; Hortobagyi, G.N.; Hung, M.C. EZH2 promotes expansion of breast tumor initiating cells through activation of RAF1- $\beta$-catenin signaling. Cancer Cell 2011, 19, 86-100. [CrossRef]

118. Esposito, F.; Tornincasa, M.; Pallante, P.; Federico, A.; Borbone, E.; Pierantoni, G.M.; Fusco, A. Down-regulation of the miR-25 and miR-30d contributes to the development of anaplastic thyroid carcinoma targeting the polycomb protein EZH2. J. Clin. Endocrinol. Metab. 2012, 97, E710-E718. [CrossRef]

119. Salvatori, B.; Iosue, I.; Djodji Damas, N.; Mangiavacchi, A.; Chiaretti, S.; Messina, M.; Padula, F.; Guarini, A.; Bozzoni, I.; Fazi, F.; et al. Critical Role of c-Myc in Acute Myeloid Leukemia Involving Direct Regulation of miR-26a and Histone Methyltransferase EZH2. Genes Cancer 2011, 2, 585-592. [CrossRef]

120. Lu, J.; He, M.L.; Wang, L.; Chen, Y.; Liu, X.; Dong, Q.; Chen, Y.C.; Peng, Y.; Yao, K.T.; Kung, H.F.; et al. MiR-26a inhibits cell growth and tumorigenesis of nasopharyngeal carcinoma through repression of EZH2. Cancer Res. 2011, 71, 225-233. [CrossRef] 
121. Huang, S.D.; Yuan, Y.; Zhuang, C.W.; Li, B.L.; Gong, D.J.; Wang, S.G.; Zeng, Z.Y.; Cheng, H.Z. MicroRNA-98 and microRNA-214 post-transcriptionally regulate enhancer of zeste homolog 2 and inhibit migration and invasion in human esophageal squamous cell carcinoma. Mol Cancer 2012, 11, 51. [CrossRef] [PubMed]

122. Alajez, N.M.; Shi, W.; Hui, A.B.; Bruce, J.; Lenarduzzi, M.; Ito, E.; Yue, S.; O'Sullivan, B.; Liu, F.F. Enhancer of Zeste homolog 2 (EZH2) is overexpressed in recurrent nasopharyngeal carcinoma and is regulated by miR-26a, miR-101, and miR-98. Cell Death Dis. 2010, 1, e85. [CrossRef] [PubMed]

123. Zheng, F.; Liao, Y.J.; Cai, M.Y.; Liu, Y.H.; Liu, T.H.; Chen, S.P.; Bian, X.W.; Guan, X.Y.; Lin, M.C.; Zeng, Y.X.; et al. The putative tumour suppressor microRNA-124 modulates hepatocellular carcinoma cell aggressiveness by repressing ROCK2 and EZH2. Gut 2012, 61, 278-289. [CrossRef]

124. Luo, C.; Merz, P.R.; Chen, Y.; Dickes, E.; Pscherer, A.; Schadendorf, D.; Eichmüller, S.B. MiR-101 inhibits melanoma cell invasion and proliferation by targeting MITF and EZH2. Cancer Lett. 2013, 341, 240-247. [CrossRef] [PubMed]

125. Kong, D.; Heath, E.; Chen, W.; Cher, M.L.; Powell, I.; Heilbrun, L.; Li, Y.; Ali, S.; Sethi, S.; Hassan, O.; et al. Loss of let-7 up-regulates EZH2 in prostate cancer consistent with the acquisition of cancer stem cell signatures that are attenuated by BR-DIM. PLoS ONE 2012, 7, e33729. [CrossRef] [PubMed]

126. Cai, K.; Wan, Y.; Sun, G.; Shi, L.; Bao, X.; Wang, Z. Let-7a inhibits proliferation and induces apoptosis by targeting EZH2 in nasopharyngeal carcinoma cells. Oncol. Rep. 2012, 28, 2101-2106. [CrossRef]

127. Qiu, S.; Huang, D.; Yin, D.; Li, F.; Li, X.; Kung, H.F.; Peng, Y. Suppression of tumorigenicity by microRNA-138 through inhibition of EZH2-CDK4/6-pRb-E2F1 signal loop in glioblastoma multiforme. Biochim. Biophys. Acta 2013, 1832, 1697-1707. [CrossRef]

128. Xie, L.; Zhang, Z.; Tan, Z.; He, R.; Zeng, X.; Xie, Y.; Li, S.; Tang, G.; Tang, H.; He, X. MicroRNA-124 inhibits proliferation and induces apoptosis by directly repressing EZH2 in gastric cancer. Mol. Cell Biochem. 2014, 392, 153-159. [CrossRef]

129. Luo, C.; Tetteh, P.W.; Merz, P.R.; Dickes, E.; Abukiwan, A.; Hotz-Wagenblatt, A.; Holland-Cunz, S.; Sinnberg, T.; Schittek, B.; Schadendorf, D.; et al. miR-137 inhibits the invasion of melanoma cells through downregulation of multiple oncogenic target genes. J. Investig. Dermatol. 2013, 133, 768-775. [CrossRef]

130. Yang, F.; Zhang, L.; Huo, X.S.; Yuan, J.H.; Xu, D.; Yuan, S.X.; Zhu, N.; Zhou, W.P.; Yang, G.S.; Wang, Y.Z.; et al. Long noncoding RNA high expression in hepatocellular carcinoma facilitates tumor growth through enhancer of zeste homolog 2 in humans. Hepatology 2011, 54, 1679-1689. [CrossRef]

131. Luo, M.; Li, Z.; Wang, W.; Zeng, Y.; Liu, Z.; Qiu, J. Long non-coding RNA H19 increases bladder cancer metastasis by associating with EZH2 and inhibiting E-cadherin expression. Cancer Lett. 2013, 333, $213-221$. [CrossRef] [PubMed]

132. Prensner, J.R.; Iyer, M.K.; Balbin, O.A.; Dhanasekaran, S.M.; Cao, Q.; Brenner, J.C.; Laxman, B.; Asangani, I.A.; Grasso, C.S.; Kominsky, H.D.; et al. Transcriptome sequencing across a prostate cancer cohort identifies PCAT-1, an unannotated lincRNA implicated in disease progression. Nat. Biotechnol. 2011, 29, 742-749. [CrossRef] [PubMed]

133. Gupta, R.A.; Shah, N.; Wang, K.C.; Kim, J.; Horlings, H.M.; Wong, D.J.; Tsai, M.C.; Hung, T.; Argani, P.; Rinn, J.L.; et al. Long non-coding RNA HOTAIR reprograms chromatin state to promote cancer metastasis. Nature 2010, 464, 1071-1076. [CrossRef] [PubMed]

134. Rinn, J.L.; Kertesz, M.; Wang, J.K.; Squazzo, S.L.; Xu, X.; Brugmann, S.A.; Goodnough, L.H.; Helms, J.A.; Farnham, P.J.; Segal, E.; et al. Functional demarcation of active and silent chromatin domains in human HOX loci by noncoding RNAs. Cell 2007, 129, 1311-1323. [CrossRef]

135. Ott, H.M.; Graves, A.P.; Pappalardi, M.B.; Huddleston, M.; Halsey, W.S.; Hughes, A.M.; Groy, A.; Dul, E.; Jiang, Y.; Bai, Y.; et al. A687V EZH2 is a driver of histone H3 lysine 27 (H3K27) hypertrimethylation. Mol. Cancer Ther. 2014, 13, 3062-3073. [CrossRef]

136. Sneeringer, C.J.; Scott, M.P.; Kuntz, K.W.; Knutson, S.K.; Pollock, R.M.; Richon, V.M.; Copeland, R.A. Coordinated activities of wild-type plus mutant EZH2 drive tumor-associated hypertrimethylation of lysine 27 on histone H3 (H3K27) in human B-cell lymphomas. Proc. Natl. Acad. Sci. USA 2010, 107, 20980-20985. [CrossRef]

137. Yap, D.B.; Chu, J.; Berg, T.; Schapira, M.; Cheng, S.W.; Moradian, A.; Morin, R.D.; Mungall, A.J.; Meissner, B.; Boyle, M.; et al. Somatic mutations at EZH2 Y641 act dominantly through a mechanism of selectively altered PRC2 catalytic activity, to increase H3K27 trimethylation. Blood 2011, 117, 2451-2459. [CrossRef] 
138. Souroullas, G.P.; Jeck, W.R.; Parker, J.S.; Simon, J.M.; Liu, J.Y.; Paulk, J.; Xiong, J.; Clark, K.S.; Fedoriw, Y.; Qi, J.; et al. An oncogenic Ezh2 mutation induces tumors through global redistribution of histone 3 lysine 27 trimethylation. Nat. Med. 2016, 22, 632-640. [CrossRef]

139. Richart, L.; Margueron, R. Drugging histone methyltransferases in cancer. Curr. Opin. Chem. Biol. 2020, 56, 51-62. [CrossRef]

140. Rinke, J.; Chase, A.; Cross, N.C.P.; Hochhaus, A.; Ernst, T. EZH2 in Myeloid Malignancies. Cells 2020, 9, 1639. [CrossRef]

141. Wilson, B.G.; Wang, X.; Shen, X.; McKenna, E.S.; Lemieux, M.E.; Cho, Y.J.; Koellhoffer, E.C.; Pomeroy, S.L.; Orkin, S.H.; Roberts, C.W. Epigenetic antagonism between polycomb and SWI/SNF complexes during oncogenic transformation. Cancer Cell 2010, 18, 316-328. [CrossRef] [PubMed]

142. Kia, S.K.; Gorski, M.M.; Giannakopoulos, S.; Verrijzer, C.P. SWI/SNF mediates polycomb eviction and epigenetic reprogramming of the INK4b-ARF-INK4a locus. Mol. Cell. Biol. 2008, 28, 3457-3464. [CrossRef] [PubMed]

143. Bitler, B.G.; Aird, K.M.; Garipov, A.; Li, H.; Amatangelo, M.; Kossenkov, A.V.; Schultz, D.C.; Liu, Q.; Shih Ie, M.; Conejo-Garcia, J.R.; et al. Synthetic lethality by targeting EZH2 methyltransferase activity in ARID1A-mutated cancers. Nat. Med. 2015, 21, 231-238. [CrossRef] [PubMed]

144. Fillmore, C.M.; Xu, C.; Desai, P.T.; Berry, J.M.; Rowbotham, S.P.; Lin, Y.J.; Zhang, H.; Marquez, V.E.; Hammerman, P.S.; Wong, K.K.; et al. EZH2 inhibition sensitizes BRG1 and EGFR mutant lung tumours to TopoII inhibitors. Nature 2015, 520, 239-242. [CrossRef] [PubMed]

145. Xu, K.; Wu, Z.J.; Groner, A.C.; He, H.H.; Cai, C.; Lis, R.T.; Wu, X.; Stack, E.C.; Loda, M.; Liu, T.; et al. EZH2 oncogenic activity in castration-resistant prostate cancer cells is Polycomb-independent. Science 2012, 338, 1465-1469. [CrossRef] [PubMed]

146. Kim, E.; Kim, M.; Woo, D.H.; Shin, Y.; Shin, J.; Chang, N.; Oh, Y.T.; Kim, H.; Rheey, J.; Nakano, I.; et al. Phosphorylation of EZH2 activates STAT3 signaling via STAT3 methylation and promotes tumorigenicity of glioblastoma stem-like cells. Cancer Cell 2013, 23, 839-852. [CrossRef]

147. Ernst, T.; Chase, A.J.; Score, J.; Hidalgo-Curtis, C.E.; Bryant, C.; Jones, A.V.; Waghorn, K.; Zoi, K.; Ross, F.M.; Reiter, A.; et al. Inactivating mutations of the histone methyltransferase gene EZH2 in myeloid disorders. Nat. Genet. 2010, 42, 722-726. [CrossRef]

148. Hirschfield, G.M.; Liu, X.; Han, Y.; Gorlov, I.P.; Lu, Y.; Xu, C.; Lu, Y.; Chen, W.; Juran, B.D.; Coltescu, C.; et al. Variants at IRF5-TNPO3, 17q12-21 and MMEL1 are associated with primary biliary cirrhosis. Nat. Genet. 2010, 42, 655-657. [CrossRef]

149. Sashida, G.; Harada, H.; Matsui, H.; Oshima, M.; Yui, M.; Harada, Y.; Tanaka, S.; Mochizuki-Kashio, M.; Wang, C.; Saraya, A.; et al. Ezh2 loss promotes development of myelodysplastic syndrome but attenuates its predisposition to leukaemic transformation. Nat. Commun. 2014, 5, 4177. [CrossRef]

150. He, W.; Cai, Q.; Sun, F.; Zhong, G.; Wang, P.; Liu, H.; Luo, J.; Yu, H.; Huang, J.; Lin, T. linc-UBC1 physically associates with polycomb repressive complex 2 (PRC2) and acts as a negative prognostic factor for lymph node metastasis and survival in bladder cancer. Biochim. Biophys. Acta 2013, 1832, 1528-1537. [CrossRef]

151. Cardoso, C.; Mignon, C.; Hetet, G.; Grandchamps, B.; Fontes, M.; Colleaux, L. The human EZH2 gene: Genomic organisation and revised mapping in 7q35 within the critical region for malignant myeloid disorders. Eur. J. Hum. Genet. 2000, 8, 174-180. [CrossRef]

152. Muto, T.; Sashida, G.; Oshima, M.; Wendt, G.R.; Mochizuki-Kashio, M.; Nagata, Y.; Sanada, M.; Miyagi, S.; Saraya, A.; Kamio, A.; et al. Concurrent loss of Ezh2 and Tet2 cooperates in the pathogenesis of myelodysplastic disorders. J. Exp. Med. 2013, 210, 2627-2639. [CrossRef] [PubMed]

153. Jankowska, A.M.; Makishima, H.; Tiu, R.V.; Szpurka, H.; Huang, Y.; Traina, F.; Visconte, V.; Sugimoto, Y.; Prince, C.; O'Keefe, C.; et al. Mutational spectrum analysis of chronic myelomonocytic leukemia includes genes associated with epigenetic regulation: UTX, EZH2, and DNMT3A. Blood 2011, 118, 3932-3941. [CrossRef] [PubMed]

154. Simon, C.; Chagraoui, J.; Krosl, J.; Gendron, P.; Wilhelm, B.; Lemieux, S.; Boucher, G.; Chagnon, P.; Drouin, S.; Lambert, R.; et al. A key role for EZH2 and associated genes in mouse and human adult T-cell acute leukemia. Genes Dev. 2012, 26, 651-656. [CrossRef]

155. Ntziachristos, P.; Tsirigos, A.; Van Vlierberghe, P.; Nedjic, J.; Trimarchi, T.; Flaherty, M.S.; Ferres-Marco, D.; da Ros, V.; Tang, Z.; Siegle, J.; et al. Genetic inactivation of the polycomb repressive complex 2 in T cell acute lymphoblastic leukemia. Nat. Med. 2012, 18, 298-301. [CrossRef] [PubMed] 
156. Agger, K.; Cloos, P.A.; Christensen, J.; Pasini, D.; Rose, S.; Rappsilber, J.; Issaeva, I.; Canaani, E.; Salcini, A.E.; Helin, K. UTX and JMJD3 are histone H3K27 demethylases involved in HOX gene regulation and development. Nature 2007, 449, 731-734. [CrossRef] [PubMed]

157. Lan, F.; Bayliss, P.E.; Rinn, J.L.; Whetstine, J.R.; Wang, J.K.; Chen, S.; Iwase, S.; Alpatov, R.; Issaeva, I.; Canaani, E.; et al. A histone H3 lysine 27 demethylase regulates animal posterior development. Nature 2007, 449, 689-694. [CrossRef]

158. De Santa, F.; Totaro, M.G.; Prosperini, E.; Notarbartolo, S.; Testa, G.; Natoli, G. The histone H3 lysine-27 demethylase Jmjd3 links inflammation to inhibition of polycomb-mediated gene silencing. Cell 2007, 130, 1083-1094. [CrossRef]

159. Hong, S.; Cho, Y.W.; Yu, L.R.; Yu, H.; Veenstra, T.D.; Ge, K. Identification of JmjC domain-containing UTX and JMJD3 as histone H3 lysine 27 demethylases. Proc. Natl. Acad. Sci. USA 2007, 104, 18439-18444. [CrossRef]

160. Smith, E.R.; Lee, M.G.; Winter, B.; Droz, N.M.; Eissenberg, J.C.; Shiekhattar, R.; Shilatifard, A. Drosophila UTX is a histone H3 Lys27 demethylase that colocalizes with the elongating form of RNA polymerase II. Mol. Cell. Biol. 2008, 28, 1041-1046. [CrossRef]

161. Blatch, L.G.; Lässle, M. The tetratricopeptide repeat: A structural motif mediating protein-protein interactions. Bioessays 1999, 21, 932-939. [CrossRef]

162. Horton, J.R.; Gale, M.; Yan, Q.; Cheng, X. The Molecular Basis of Histone Demethylation, in DNA and Histone Methylation as Cancer Targets; Kaneda, A., Tsukada, Y.-I., Eds.; Springer International Publishing: Cham, Switzerland, 2017; pp. 151-219.

163. Hübner, R.M.; Spector, D.L. Role of H3K27 demethylases Jmjd3 and UTX in transcriptional regulation. Cold Spring Harb. Symp. Quant. Biol. 2010, 75, 43-49. [CrossRef] [PubMed]

164. Walport, L.J.; Hopkinson, R.J.; Vollmar, M.; Madden, S.K.; Gileadi, C.; Oppermann, U.; Schofield, C.J.; Johansson, C. Human UTY(KDM6C) is a male-specific Ne-methyl lysyl demethylase. J. Biol. Chem. 2014, 289, 18302-18313. [CrossRef] [PubMed]

165. Shpargel, K.B.; Sengoku, T.; Yokoyama, S.; Magnuson, T. UTX and UTY demonstrate histone demethylase-independent function in mouse embryonic development. PLoS Genet 2012, 8, e1002964. [CrossRef]

166. Chakraborty, A.A.; Laukka, T.; Myllykoski, M.; Ringel, A.E.; Booker, M.A.; Tolstorukov, M.Y.; Meng, Y.J.; Meier, S.R.; Jennings, R.B.; Creech, A.L.; et al. Histone demethylase KDM6A directly senses oxygen to control chromatin and cell fate. Science 2019, 363, 1217-1222. [CrossRef]

167. Issaeva, I.; Zonis, Y.; Rozovskaia, T.; Orlovsky, K.; Croce, C.M.; Nakamura, T.; Mazo, A.; Eisenbach, L.; Canaani, E. Knockdown of ALR (MLL2) reveals ALR target genes and leads to alterations in cell adhesion and growth. Mol. Cell Biol. 2007, 27, 1889-1903. [CrossRef]

168. Cho, Y.W.; Hong, T.; Hong, S.; Guo, H.; Yu, H.; Kim, D.; Guszczynski, T.; Dressler, G.R.; Copeland, T.D.; Kalkum, M.; et al. PTIP associates with MLL3- and MLL4-containing histone H3 lysine 4 methyltransferase complex. J. Biol. Chem. 2007, 282, 20395-20406. [CrossRef]

169. Mohan, M.; Herz, H.M.; Smith, E.R.; Zhang, Y.; Jackson, J.; Washburn, M.P.; Florens, L.; Eissenberg, J.C.; Shilatifard, A. The COMPASS family of H3K4 methylases in Drosophila. Mol. Cell. Biol. 2011, 31, 4310-4318. [CrossRef]

170. Vandamme, J.; Lettier, G.; Sidoli, S.; Di Schiavi, E.; Nørregaard Jensen, O.; Salcini, A.E. The C. elegans H3K27 demethylase UTX-1 is essential for normal development, independent of its enzymatic activity. PLoS Genet. 2012, 8, e1002647. [CrossRef]

171. Lee, M.G.; Villa, R.; Trojer, P.; Norman, J.; Yan, K.P.; Reinberg, D.; Di Croce, L.; Shiekhattar, R. Demethylation of H3K27 regulates polycomb recruitment and H2A ubiquitination. Science 2007, 318, 447-450. [CrossRef]

172. Hodges, C.; Kirkland, J.G.; Crabtree, G.R. The Many Roles of BAF (mSWI/SNF) and PBAF Complexes in Cancer. Cold Spring Harb. Perspect. Med. 2016, 6, a026930. [CrossRef] [PubMed]

173. Arcipowski, M.K.; Martinez, C.A.; Ntziachristos, P. Histone demethylases in physiology and cancer: A tale of two enzymes, JMJD3 and UTX. Curr. Opin. Genet. Dev. 2016, 36, 59-67. [CrossRef] [PubMed]

174. Perrigue, M.P.; Najbauer, J.; Barciszewski, J. Histone demethylase JMJD3 at the intersection of cellular senescence and cancer. Biochim. Biophys. Acta 2016, 1865, 237-244. [CrossRef]

175. Ntziachristos, P.; Tsirigos, A.; Welstead, G.G.; Trimarchi, T.; Bakogianni, S.; Xu, L.; Loizou, E.; Holmfeldt, L.; Strikoudis, A.; King, B.; et al. Contrasting roles of histone 3 lysine 27 demethylases in acute lymphoblastic leukaemia. Nature 2014, 514, 513-517. [CrossRef] [PubMed] 
176. Van der Meulen, J.; Sanghvi, V.; Mavrakis, K.; Durinck, K.; Fang, F.; Matthijssens, F.; Rondou, P.; Rosen, M.; Pieters, T.; Vandenberghe, P.; et al. The H3K27me3 demethylase UTX is a gender-specific tumor suppressor in T-cell acute lymphoblastic leukemia. Blood 2015, 125, 13-21. [CrossRef] [PubMed]

177. Herz,H.M.; Madden, L.D.; Chen, Z.; Bolduc, C.; Buff, E.; Gupta, R.; Davuluri, R.; Shilatifard, A.; Hariharan, I.K.; Bergmann, A. The H3K27me3 demethylase dUTX is a suppressor of Notch- and Rb-dependent tumors in Drosophila. Mol. Cell. Biol. 2010, 30, 2485-2497. [CrossRef] [PubMed]

178. Robinson, G.; Parker, M.; Kranenburg, T.A.; Lu, C.; Chen, X.; Ding, L.; Phoenix, T.N.; Hedlund, E.; Wei, L.; Zhu, X.; et al. Novel mutations target distinct subgroups of medulloblastoma. Nature 2012, 488, 43-48. [CrossRef] [PubMed]

179. Mar, B.G.; Bullinger, L.; Basu, E.; Schlis, K.; Silverman, L.B.; Döhner, K.; Armstrong, S.A. Sequencing histone-modifying enzymes identifies UTX mutations in acute lymphoblastic leukemia. Leukemia 2012, 26, 1881-1883. [CrossRef]

180. Dalgliesh, G.L.; Furge, K.; Greenman, C.; Chen, L.; Bignell, G.; Butler, A.; Davies, H.; Edkins, S.; Hardy, C.; Latimer, $\mathrm{C}$; et al. Systematic sequencing of renal carcinoma reveals inactivation of histone modifying genes. Nature 2010, 463, 360-363. [CrossRef]

181. Nickerson, M.L.; Dancik, G.M.; Im, K.M.; Edwards, M.G.; Turan, S.; Brown, J.; Ruiz-Rodriguez, C.; Owens, C.; Costello, J.C.; Guo, G.; et al. Concurrent alterations in TERT, KDM6A, and the BRCA pathway in bladder cancer. Clin. Cancer Res. 2014, 20, 4935-4948. [CrossRef]

182. Gui, Y.; Guo, G.; Huang, Y.; Hu, X.; Tang, A.; Gao, S.; Wu, R.; Chen, C.; Li, X.; Zhou, L.; et al. Frequent mutations of chromatin remodeling genes in transitional cell carcinoma of the bladder. Nat. Genet. 2011, 43, 875-878. [CrossRef] [PubMed]

183. van Haaften, G.; Dalgliesh, G.L.; Davies, H.; Chen, L.; Bignell, G.; Greenman, C.; Edkins, S.; Hardy, C.; O'Meara, S.; Teague, J.; et al. Somatic mutations of the histone H3K27 demethylase gene UTX in human cancer. Nat. Genet. 2009, 41, 521-523. [CrossRef] [PubMed]

184. Dyrskjøt, L.; Kruhøffer, M.; Thykjaer, T.; Marcussen, N.; Jensen, J.L.; Møller, K.; Ørntoft, T.F. Gene expression in the urinary bladder: A common carcinoma in situ gene expression signature exists disregarding histopathological classification. Cancer Res. 2004, 64, 4040-4048. [CrossRef] [PubMed]

185. Cromer, A.; Carles, A.; Millon, R.; Ganguli, G.; Chalmel, F.; Lemaire, F.; Young, J.; Dembélé, D.; Thibault, C.; Muller, D.; et al. Identification of genes associated with tumorigenesis and metastatic potential of hypopharyngeal cancer by microarray analysis. Oncogene 2004, 23, 2484-2498. [CrossRef] [PubMed]

186. Talantov, D.; Mazumder, A.; Yu, J.X.; Briggs, T.; Jiang, Y.; Backus, J.; Atkins, D.; Wang, Y. Novel genes associated with malignant melanoma but not benign melanocytic lesions. Clin. Cancer Res. 2005, 11, 7234-7242. [CrossRef] [PubMed]

187. Tomlins, S.A.; Mehra, R.; Rhodes, D.R.; Cao, X.; Wang, L.; Dhanasekaran, S.M.; Kalyana-Sundaram, S.; Wei, J.T.; Rubin, M.A.; Pienta, K.J.; et al. Integrative molecular concept modeling of prostate cancer progression. Nat. Genet. 2007, 39, 41-51. [CrossRef]

188. Bonome, T.; Levine, D.A.; Shih, J.; Randonovich, M.; Pise-Masison, C.A.; Bogomolniy, F.; Ozbun, L.; Brady, J.; Barrett, J.C.; Boyd, J.; et al. A gene signature predicting for survival in suboptimally debulked patients with ovarian cancer. Cancer Res. 2008, 68, 5478-5486. [CrossRef]

189. Patani, N.; Jiang, W.G.; Newbold, R.F.; Mokbel, K. Histone-modifier gene expression profiles are associated with pathological and clinical outcomes in human breast cancer. Anticancer Res. 2011, 31, 4115-4125.

190. Choi, Y.L.; Tsukasaki, K.; O’Neill, M.C.; Yamada, Y.; Onimaru, Y.; Matsumoto, K.; Ohashi, J.; Yamashita, Y.; Tsutsumi, S.; Kaneda, R.; et al. A genomic analysis of adult T-cell leukemia. Oncogene 2007, 26, 1245-1255. [CrossRef]

191. Manna, S.; Kim, J.K.; Baugé, C.; Cam, M.; Zhao, Y.; Shetty, J.; Vacchio, M.S.; Castro, E.; Tran, B.; Tessarollo, L.; et al. Histone H3 Lysine 27 demethylases Jmjd3 and Utx are required for T-cell differentiation. Nat. Commun. 2015, 6, 8152. [CrossRef]

192. Benyoucef, A.; Palii, C.G.; Wang, C.; Porter, C.J.; Chu, A.; Dai, F.; Tremblay, V.; Rakopoulos, P.; Singh, K.; Huang, S.; et al. UTX inhibition as selective epigenetic therapy against TAL1-driven T-cell acute lymphoblastic leukemia. Genes Dev. 2016, 30, 508-521. [CrossRef] [PubMed]

193. Wang, L.; Shilatifard, A. UTX Mutations in Human Cancer. Cancer Cell 2019, 35, 168-176. [CrossRef] [PubMed] 
194. Jones, T.D.; Eble, J.N.; Wang, M.; MacLennan, G.T.; Delahunt, B.; Brunelli, M.; Martignoni, G.; Lopez-Beltran, A.; Bonsib, S.M.; Ulbright, T.M.; et al. Molecular genetic evidence for the independent origin of multifocal papillary tumors in patients with papillary renal cell carcinomas. Clin. Cancer Res. 2005, 11, 7226-7233. [CrossRef] [PubMed]

195. Sun, L.; Hui, A.M.; Su, Q.; Vortmeyer, A.; Kotliarov, Y.; Pastorino, S.; Passaniti, A.; Menon, J.; Walling, J.; Bailey, R.; et al. Neuronal and glioma-derived stem cell factor induces angiogenesis within the brain. Cancer Cell. 2006, 9, 287-300. [CrossRef]

196. Hou, G.; Le Blancq, S.M.; E, Y.; Zhu, H.; Lee, M.G. Structure of a frequently rearranged rRNA-encoding chromosome in Giardia lamblia. Nucleic Acids Res. 1995, 23, 3310-3317. [CrossRef]

197. Agger, K.; Cloos, P.A.; Rudkjaer, L.; Williams, K.; Andersen, G.; Christensen, J.; Helin, K. The H3K27me3 demethylase JMJD3 contributes to the activation of the INK4A-ARF locus in response to oncogene- and stress-induced senescence. Genes Dev. 2009, 23, 1171-1176. [CrossRef]

198. Piccaluga, P.P.; Agostinelli, C.; Califano, A.; Rossi, M.; Basso, K.; Zupo, S.; Went, P.; Klein, U.; Zinzani, P.L.; Baccarani, M.; et al. Gene expression analysis of peripheral T cell lymphoma, unspecified, reveals distinct profiles and new potential therapeutic targets. J. Clin. Investig. 2007, 117, 823-834. [CrossRef]

199. Gozdecka, M.; Meduri, E.; Mazan, M.; Tzelepis, K.; Dudek, M.; Knights, A.J.; Pardo, M.; Yu, L.; Choudhary, J.S.; Metzakopian, E.; et al. UTX-mediated enhancer and chromatin remodeling suppresses myeloid leukemogenesis through noncatalytic inverse regulation of ETS and GATA programs. Nat. Genet. 2018, 50, 883-894. [CrossRef]

200. Schulz, W.A.; Lang, A.; Koch, J.; Greife, A. The histone demethylase UTX/KDM6A in cancer: Progress and puzzles. Int. J. Cancer 2019, 145, 614-620. [CrossRef]

201. Guo, G.; Sun, X.; Chen, C.; Wu, S.; Huang, P.; Li, Z.; Dean, M.; Huang, Y.; Jia, W.; Zhou, Q.; et al. Whole-genome and whole-exome sequencing of bladder cancer identifies frequent alterations in genes involved in sister chromatid cohesion and segregation. Nat. Genet. 2013, 45, 1459-1463. [CrossRef]

202. Waddell, N.; Pajic, M.; Patch, A.M.; Chang, D.K.; Kassahn, K.S.; Bailey, P.; Johns, A.L.; Miller, D.; Nones, K.; Quek, K.; et al. Whole genomes redefine the mutational landscape of pancreatic cancer. Nature 2015, 518, 495-501. [CrossRef] [PubMed]

203. Wang, J.K.; Tsai, M.C.; Poulin, G.; Adler, A.S.; Chen, S.; Liu, H.; Shi, Y.; Chang, H.Y. The histone demethylase UTX enables RB-dependent cell fate control. Genes Dev. 2010, 24, 327-332. [CrossRef] [PubMed]

204. Kim, J.H.; Sharma, A.; Dhar, S.S.; Lee, S.H.; Gu, B.; Chan, C.H.; Lin, H.K.; Lee, M.G. UTX and MLL4 coordinately regulate transcriptional programs for cell proliferation and invasiveness in breast cancer cells. Cancer Res. 2014, 74, 1705-1717. [CrossRef] [PubMed]

205. Yomtoubian, S.; Lee, S.B.; Verma, A.; Izzo, F.; Markowitz, G.; Choi, H.; Cerchietti, L.; Vahdat, L.; Brown, K.A.; Andreopoulou, E.; et al. Inhibition of EZH2 Catalytic Activity Selectively Targets a Metastatic Subpopulation in Triple-Negative Breast Cancer. Cell Rep. 2020, 30, 755-770. [CrossRef] [PubMed]

206. Bracken, A.P.; Kleine-Kohlbrecher, D.; Dietrich, N.; Pasini, D.; Gargiulo, G.; Beekman, C.; Theilgaard-Mönch, K.; Minucci, S.; Porse, B.T.; Marine, J.C.; et al. The Polycomb group proteins bind throughout the INK4A-ARF locus and are disassociated in senescent cells. Genes Dev. 2007, 21, 525-530. [CrossRef]

207. Kotake, Y.; Cao, R.; Viatour, P.; Sage, J.; Zhang, Y.; Xiong, Y. pRB family proteins are required for H3K27 trimethylation and Polycomb repression complexes binding to and silencing p16INK4alpha tumor suppressor gene. Genes Dev. 2007, 21, 49-54. [CrossRef]

208. Ene, C.I.; Edwards, L.; Riddick, G.; Baysan, M.; Woolard, K.; Kotliarova, S.; Lai, C.; Belova, G.; Cam, M.; Walling, J.; et al. Histone demethylase Jumonji D3 (JMJD3) as a tumor suppressor by regulating p53 protein nuclear stabilization. PLoS ONE 2012, 7, e51407. [CrossRef] [PubMed]

209. Williams, K.; Christensen, J.; Rappsilber, J.; Nielsen, A.L.; Johansen, J.V.; Helin, K. The histone lysine demethylase JMJD3/KDM6B is recruited to p53 bound promoters and enhancer elements in a p53 dependent manner. PLoS ONE 2014, 9, e96545. [CrossRef]

210. Park, W.Y.; Hong, B.J.; Lee, J.; Choi, C.; Kim, M.Y. H3K27 Demethylase JMJD3 Employs the NF-kB and BMP Signaling Pathways to Modulate the Tumor Microenvironment and Promote Melanoma Progression and Metastasis. Cancer Res. 2016, 76, 161-170. [CrossRef] 
211. Zhang, Y.; Shen, L.; Stupack, D.G.; Bai, N.; Xun, J.; Ren, G.; Han, J.; Li, L.; Luo, Y.; Xiang, R.; et al. JMJD3 promotes survival of diffuse large B-cell lymphoma subtypes via distinct mechanisms. Oncotarget 2016, 7, 29387-29399. [CrossRef]

212. Zhang, P.P.; Wang, X.L.; Zhao, W.; Qi, B.; Yang, Q.; Wan, H.Y.; Shuang, Z.Y.; Liu, M.; Li, X.; Li, S.; et al. DNA methylation-mediated repression of miR-941 enhances lysine (K)-specific demethylase 6B expression in hepatoma cells. J. Biol. Chem. 2014, 289, 24724-24735. [CrossRef] [PubMed]

213. Mo, J.; Wang, L.; Huang, X.; Lu, B.; Zou, C.; Wei, L.; Chu, J.; Eggers, P.K.; Chen, S.; Raston, C.L.; et al. Multifunctional nanoparticles for co-delivery of paclitaxel and carboplatin against ovarian cancer by inactivating the JMJD3-HER2 axis. Nanoscale 2017, 9, 13142-13152. [CrossRef] [PubMed]

214. Liang, S.; Yao, Q.; Wei, D.; Liu, M.; Geng, F.; Wang, Q.; Wang, Y.-s. KDM6B promotes ovarian cancer cell migration and invasion by induced transforming growth factor- $\beta 1$ expression. J. Cell. Biochem. 2019, 120, 493-506. [CrossRef] [PubMed]

215. Lee, S.W.; Park, D.Y.; Kim, M.-Y.; Kang, C. Synergistic triad epistasis of epigenetic H3K27me modifier genes, EZH2, KDM6A, and KDM6B, in gastric cancer susceptibility. Gastric Cancer 2019, 22, 640-644. [CrossRef] [PubMed]

216. Li, Y.; Zhang, M.; Sheng, M.; Zhang, P.; Chen, Z.; Xing, W.; Bai, J.; Cheng, T.; Yang, F.C.; Zhou, Y. Therapeutic potential of GSK-J4, a histone demethylase KDM6B/JMJD3 inhibitor, for acute myeloid leukemia. J. Cancer Res. Clin. Oncol. 2018, 144, 1065-1077. [CrossRef]

217. Nagarsheth, N.; Peng, D.; Kryczek, I.; Wu, K.; Li, W.; Zhao, E.; Zhao, L.; Wei, S.; Frankel, T.; Vatan, L.; et al. PRC2 Epigenetically Silences Th1-Type Chemokines to Suppress Effector T-Cell Trafficking in Colon Cancer. Cancer Res. 2016, 76, 275-282. [CrossRef]

218. Jin, Q.; Martinez, C.A.; Arcipowski, K.M.; Zhu, Y.; Gutierrez-Diaz, B.T.; Wang, K.K.; Johnson, M.R.; Volk, A.G.; Wang, F.; Wu, J.; et al. USP7 Cooperates with NOTCH1 to Drive the Oncogenic Transcriptional Program in T-Cell Leukemia. Clin. Cancer Res. 2019, 25, 222-239. [CrossRef]

219. Sui, A.; Xu, Y.; Yang, J.; Pan, B.; Wu, J.; Guo, T.; Shen, Y.; Guo, X. The histone H3 Lys 27 demethylase KDM6B promotes migration and invasion of glioma cells partly by regulating the expression of SNAI1. Neurochem. Int. 2019, 124, 123-129. [CrossRef]

220. Yin, X.; Yang, S.; Zhang, M.; Yue, Y. The role and prospect of JMJD3 in stem cells and cancer. Biomed. Pharmacother. 2019, 118, 109384. [CrossRef]

221. Pugh, T.J.; Weeraratne, S.D.; Archer, T.C.; Pomeranz Krummel, D.A.; Auclair, D.; Bochicchio, J.; Carneiro, M.O.; Carter, S.L.; Cibulskis, K.; Erlich, R.L.; et al. Medulloblastoma exome sequencing uncovers subtype-specific somatic mutations. Nature 2012, 488, 106-110. [CrossRef]

222. Schwartzentruber, J.; Korshunov, A.; Liu, X.Y.; Jones, D.T.; Pfaff, E.; Jacob, K.; Sturm, D.; Fontebasso, A.M.; Quang, D.A.; Tönjes, M.; et al. Driver mutations in histone H3.3 and chromatin remodelling genes in paediatric glioblastoma. Nature 2012, 482, 226-231. [CrossRef] [PubMed]

223. Wu, G.; Broniscer, A.; McEachron, T.A.; Lu, C.; Paugh, B.S.; Becksfort, J.; Qu, C.; Ding, L.; Huether, R.; Parker, M.; et al. Somatic histone H3 alterations in pediatric diffuse intrinsic pontine gliomas and non-brainstem glioblastomas. Nat. Genet. 2012, 44, 251-253. [PubMed]

224. Sturm, D.; Witt, H.; Hovestadt, V.; Khuong-Quang, D.A.; Jones, D.T.; Konermann, C.; Pfaff, E.; Tönjes, M.; Sill, M.; Bender, S.; et al. Hotspot mutations in H3F3A and IDH1 define distinct epigenetic and biological subgroups of glioblastoma. Cancer Cell 2012, 22, 425-437. [CrossRef] [PubMed]

225. Lowe, B.R.; Maxham, L.A.; Hamey, J.J.; Wilkins, M.R.; Partridge, J.F. Histone H3 Mutations: An Updated View of Their Role in Chromatin Deregulation and Cancer. Cancers (Basel) 2019, 11, 660. [CrossRef] [PubMed]

226. Nacev, B.A.; Feng, L.; Bagert, J.D.; Lemiesz, A.E.; Gao, J.; Soshnev, A.A.; Kundra, R.; Schultz, N.; Muir, T.W.; Allis, C.D. The expanding landscape of 'oncohistone' mutations in human cancers. Nature 2019, 567, 473-478. [CrossRef]

227. Papillon-Cavanagh, S.; Lu, C.; Gayden, T.; Mikael, L.G.; Bechet, D.; Karamboulas, C.; Ailles, L.; Karamchandani, J.; Marchione, D.M.; Garcia, B.A.; et al. Impaired H3K36 methylation defines a subset of head and neck squamous cell carcinomas. Nat. Genet. 2017, 49, 180-185. [CrossRef]

228. Kleinschmidt-DeMasters, B.K.; Donson, A.; Foreman, N.K.; Dorris, K. H3 K27M Mutation in Gangliogliomas can be Associated with Poor Prognosis. Brain Pathol. 2017, 27, 846-850. [CrossRef] 
229. Lehnertz, B.; Zhang, Y.W.; Boivin, I.; Mayotte, N.; Tomellini, E.; Chagraoui, J.; Lavallée, V.P.; Hébert, J.; Sauvageau, G. H3(K27M/I) mutations promote context-dependent transformation in acute myeloid leukemia with RUNX1 alterations. Blood 2017, 130, 2204-2214. [CrossRef]

230. Behjati, S.; Tarpey, P.S.; Presneau, N.; Scheipl, S.; Pillay, N.; Van Loo, P.; Wedge, D.C.; Cooke, S.L.; Gundem, G.; Davies, H.; et al. Distinct H3F3A and H3F3B driver mutations define chondroblastoma and giant cell tumor of bone. Nat. Genet. 2013, 45, 1479-1482. [CrossRef]

231. Weinberg, N.D.; Allis, C.D.; Lu, C. Oncogenic Mechanisms of Histone H3 Mutations. Cold Spring Harb. Perspect. Med. 2017, 7, a026443. [CrossRef]

232. Witt, O.; Albig, W.; Doenecke, D. Testis-specific expression of a novel human H3 histone gene. Exp. Cell Res. 1996, 229, 301-306. [CrossRef]

233. Wiedemann, S.M.; Mildner, S.N.; Bönisch, C.; Israel, L.; Maiser, A.; Matheisl, S.; Straub, T.; Merkl, R.; Leonhardt, H.; Kremmer, E.; et al. Identification and characterization of two novel primate-specific histone H3 variants, H3.X and H3.Y. J. Cell. Biol. 2010, 190, 777-791. [CrossRef] [PubMed]

234. Wu, S.R.; Tsai, S.; Bonner, W.M. Patterns of histone variant synthesis can distinguish G0 from G1 cells. Cell 1982, 31, 367-374. [CrossRef]

235. Wong, L.H.; McGhie, J.D.; Sim, M.; Anderson, M.A.; Ahn, S.; Hannan, R.D.; George, A.J.; Morgan, K.A.; Mann, J.R.; Choo, K.H. ATRX interacts with H3.3 in maintaining telomere structural integrity in pluripotent embryonic stem cells. Genome Res. 2010, 20, 351-360. [CrossRef]

236. Lewis, P.W.; Elsaesser, S.J.; Noh, K.M.; Stadler, S.C.; Allis, C.D. Daxx is an H3.3-specific histone chaperone and cooperates with ATRX in replication-independent chromatin assembly at telomeres. Proc. Natl. Acad. Sci. USA 2010, 107, 14075-14080. [CrossRef] [PubMed]

237. Drané, P.; Ouararhni, K.; Depaux, A.; Shuaib, M.; Hamiche, A. The death-associated protein DAXX is a novel histone chaperone involved in the replication-independent deposition of H3.3. Genes Dev. 2010, 24, 1253-1265. [CrossRef]

238. Tagami, H.; Ray-Gallet, D.; Almouzni, G.; Nakatani, Y. Histone H3.1 and H3.3 complexes mediate nucleosome assembly pathways dependent or independent of DNA synthesis. Cell 2004, 116, 51-61. [CrossRef]

239. Szenker, E.; Ray-Gallet, D.; Almouzni, G. The double face of the histone variant H3.3. Cell Res. 2011, 21, 421-434. [CrossRef] [PubMed]

240. Filipescu, D.; Szenker, E.; Almouzni, G. Developmental roles of histone H3 variants and their chaperones. Trends Genet. 2013, 29, 630-640. [CrossRef] [PubMed]

241. Goldberg, A.D.; Banaszynski, L.A.; Noh, K.M.; Lewis, P.W.; Elsaesser, S.J.; Stadler, S.; Dewell, S.; Law, M.; Guo, X.; Li, X.; et al. Distinct factors control histone variant H3.3 localization at specific genomic regions. Cell 2010, 140, 678-691. [CrossRef] [PubMed]

242. Delbarre, E.; Jacobsen, B.M.; Reiner, A.H.; Sørensen, A.L.; Küntziger, T.; Collas, P. Chromatin environment of histone variant H3.3 revealed by quantitative imaging and genome-scale chromatin and DNA immunoprecipitation. Mol. Biol. Cell. 2010, 21, 1872-1884. [CrossRef] [PubMed]

243. Bender, S.; Tang, Y.; Lindroth, A.M.; Hovestadt, V.; Jones, D.T.; Kool, M.; Zapatka, M.; Northcott, P.A.; Sturm, D.; Wang, W.; et al. Reduced H3K27me3 and DNA hypomethylation are major drivers of gene expression in K27M mutant pediatric high-grade gliomas. Cancer Cell 2013, 24, 660-672. [CrossRef] [PubMed]

244. Chan, K.M.; Fang, D.; Gan, H.; Hashizume, R.; Yu, C.; Schroeder, M.; Gupta, N.; Mueller, S.; James, C.D.; Jenkins, R.; et al. The histone H3.3K27M mutation in pediatric glioma reprograms H3K27 methylation and gene expression. Genes Dev. 2013, 27, 985-990. [CrossRef] [PubMed]

245. Funato, K.; Major, T.; Lewis, P.W.; Allis, C.D.; Tabar, V. Use of human embryonic stem cells to model pediatric gliomas with H3.3K27M histone mutation. Science 2014, 346, 1529-1533. [CrossRef] [PubMed]

246. Wang, G.G.; Cai, L.; Pasillas, M.P.; Kamps, M.P. NUP98-NSD1 links H3K36 methylation to Hox-A gene activation and leukaemogenesis. Nat. Cell Biol. 2007, 9, 804-812. [CrossRef] [PubMed]

247. Bush, K.M.; Yuen, B.T.; Barrilleaux, B.L.; Riggs, J.W.; O'Geen, H.; Cotterman, R.F.; Knoepfler, P.S. Endogenous mammalian histone H3.3 exhibits chromatin-related functions during development. Epigenet. Chromatin. 2013, 6, 7. [CrossRef]

248. Lin, J.C.; Conti, M.; Ramalho-Santos, M. Histone variant H3.3 maintains a decondensed chromatin state essential for mouse preimplantation development. Development 2013, 140, 3624-3634. [CrossRef]

249. Falkenberg, J.K.; Johnstone, R.W. Histone deacetylases and their inhibitors in cancer, neurological diseases and immune disorders. Nat. Rev. Drug Discov. 2014, 13, 673-691. [CrossRef] 
250. Mulligan, P.; Westbrook, T.F.; Ottinger, M.; Pavlova, N.; Chang, B.; Macia, E.; Shi, Y.J.; Barretina, J.; Liu, J.; Howley, P.M.; et al. CDYL bridges REST and histone methyltransferases for gene repression and suppression of cellular transformation. Mol. Cell 2008, 32, 718-726. [CrossRef]

251. Zhang, Y.; Yang, X.; Gui, B.; Xie, G.; Zhang, D.; Shang, Y.; Liang, J. Corepressor protein CDYL functions as a molecular bridge between polycomb repressor complex 2 and repressive chromatin mark trimethylated histone lysine 27. J. Biol. Chem. 2011, 286, 42414-42425. [CrossRef]

252. Federico, A.; Pallante, P.; Bianco, M.; Ferraro, A.; Esposito, F.; Monti, M.; Cozzolino, M.; Keller, S.; Fedele, M.; Leone, V.; et al. Chromobox protein homologue 7 protein, with decreased expression in human carcinomas, positively regulates E-cadherin expression by interacting with the histone deacetylase 2 protein. Cancer Res. 2009, 69, 7079-7087. [CrossRef] [PubMed]

253. Forzati, F.; Federico, A.; Pallante, P.; Abbate, A.; Esposito, F.; Malapelle, U.; Sepe, R.; Palma, G.; Troncone, G.; Scarfò, M.; et al. CBX7 is a tumor suppressor in mice and humans. J. Clin. Investig. 2012, 122, 612-623. [CrossRef] [PubMed]

254. Pallante, P.; Sepe, R.; Federico, A.; Forzati, F.; Bianco, M.; Fusco, A. CBX7 modulates the expression of genes critical for cancer progression. PLoS ONE 2014, 9, e98295. [CrossRef] [PubMed]

255. Klauke, K.; Radulović, V.; Broekhuis, M.; Weersing, E.; Zwart, E.; Olthof, S.; Ritsema, M.; Bruggeman, S.; $\mathrm{Wu}, \mathrm{X}$;; Helin, K.; et al. Polycomb Cbx family members mediate the balance between haematopoietic stem cell self-renewal and differentiation. Nat. Cell Biol. 2013, 15, 353-362. [CrossRef] [PubMed]

256. Khan, S.N.; Jankowska, A.M.; Mahfouz, R.; Dunbar, A.J.; Sugimoto, Y.; Hosono, N.; Hu, Z.; Cheriyath, V.; Vatolin, S.; Przychodzen, B.; et al. Multiple mechanisms deregulate EZH2 and histone H3 lysine 27 epigenetic changes in myeloid malignancies. Leukemia 2013, 27, 1301-1309. [CrossRef]

257. Score, J.; Hidalgo-Curtis, C.; Jones, A.V.; Winkelmann, N.; Skinner, A.; Ward, D.; Zoi, K.; Ernst, T.; Stegelmann, F.; Döhner, K.; et al. Inactivation of polycomb repressive complex 2 components in myeloproliferative and myelodysplastic/myeloproliferative neoplasms. Blood 2012, 119, 1208-1213. [CrossRef]

258. Ueda, T.; Sanada, M.; Matsui, H.; Yamasaki, N.; Honda, Z.I.; Shih, L.Y.; Mori, H.; Inaba, T.; Ogawa, S.; Honda, $\mathrm{H}$. EED mutants impair polycomb repressive complex 2 in myelodysplastic syndrome and related neoplasms. Leukemia 2012, 26, 2557-2560. [CrossRef]

259. Keats, J.J.; Maxwell, C.A.; Taylor, B.J.; Hendzel, M.J.; Chesi, M.; Bergsagel, P.L.; Larratt, L.M.; Mant, M.J.; Reiman, T.; Belch, A.R.; et al. Overexpression of transcripts originating from the MMSET locus characterizes all $\mathrm{t}(4 ; 14)(\mathrm{p} 16 ; \mathrm{q} 32)$-positive multiple myeloma patients. Blood 2005, 105, 4060-4069. [CrossRef]

260. Keats, J.J.; Reiman, T.; Maxwell, C.A.; Taylor, B.J.; Larratt, L.M.; Mant, M.J.; Belch, A.R.; Pilarski, L.M. In multiple myeloma, $\mathrm{t}(4 ; 14)(\mathrm{p} 16 ; \mathrm{q} 32)$ is an adverse prognostic factor irrespective of FGFR3 expression. Blood 2003, 101, 1520-1529. [CrossRef]

261. Ezponda, T.; Popovic, R.; Shah, M.Y.; Martinez-Garcia, E.; Zheng, Y.; Min, D.J.; Will, C.; Neri, A.; Kelleher, N.L.; Yu, J.; et al. The histone methyltransferase MMSET/WHSC1 activates TWIST1 to promote an epithelial-mesenchymal transition and invasive properties of prostate cancer. Oncogene 2013, 32, 2882-2890. [CrossRef]

262. Popovic, R.; Martinez-Garcia, E.; Giannopoulou, E.G.; Zhang, Q.; Zhang, Q.; Ezponda, T.; Shah, M.Y.; Zheng, Y.; Will, C.M.; Small, E.C.; et al. Histone methyltransferase MMSET/NSD2 alters EZH2 binding and reprograms the myeloma epigenome through global and focal changes in H3K36 and H3K27 methylation. PLoS Genet. 2014, 10, e1004566. [CrossRef] [PubMed]

263. Oyer, J.A.; Huang, X.; Zheng, Y.; Shim, J.; Ezponda, T.; Carpenter, Z.; Allegretta, M.; Okot-Kotber, C.I.; Patel, J.P.; Melnick, A.; et al. Point mutation E1099K in MMSET/NSD2 enhances its methyltranferase activity and leads to altered global chromatin methylation in lymphoid malignancies. Leukemia 2014, 28, 198-201. [CrossRef] [PubMed]

264. Jaffe, J.D.; Wang, Y.; Chan, H.M.; Zhang, J.; Huether, R.; Kryukov, G.V.; Bhang, H.E.; Taylor, J.E.; Hu, M.; Englund, N.P.; et al. Global chromatin profiling reveals NSD2 mutations in pediatric acute lymphoblastic leukemia. Nat. Genet. 2013, 45, 1386-1391. [CrossRef] [PubMed]

265. Yuan, W.; Wu, T.; Fu, H.; Dai, C.; Wu, H.; Liu, N.; Li, X.; Xu, M.; Zhang, Z.; Niu, T.; et al. Dense chromatin activates Polycomb repressive complex 2 to regulate H3 lysine 27 methylation. Science 2012, 337, 971-975. [CrossRef] 
266. Lawrence, M.S.; Stojanov, P.; Mermel, C.H.; Robinson, J.T.; Garraway, L.A.; Golub, T.R.; Meyerson, M.; Gabriel, S.B.; Lander, E.S.; Getz, G. Discovery and saturation analysis of cancer genes across 21 tumour types. Nature 2014, 505, 495-501. [CrossRef]

267. Kim, K.H.; Kim, W.; Howard, T.P.; Vazquez, F.; Tsherniak, A.; Wu, J.N.; Wang, W.; Haswell, J.R.; Walensky, L.D.; Hahn, W.C.; et al. SWI/SNF-mutant cancers depend on catalytic and non-catalytic activity of EZH2. Nat. Med. 2015, 21, 1491-1496. [CrossRef]

268. van der Vlag, J.; Otte, A.P. Transcriptional repression mediated by the human polycomb-group protein EED involves histone deacetylation. Nat. Genet. 1999, 23, 474-478. [CrossRef]

269. Song, C.; Pan, X.; Ge, Z.; Gowda, C.; Ding, Y.; Li, H.; Li, Z.; Yochum, G.; Muschen, M.; Li, Q.; et al. Epigenetic regulation of gene expression by Ikaros, HDAC1 and Casein Kinase II in leukemia. Leukemia 2016, 30, 1436-1440. [CrossRef]

270. Adams, H.; Fritzsche, F.R.; Dirnhofer, S.; Kristiansen, G.; Tzankov, A. Class I histone deacetylases 1, 2 and 3 are highly expressed in classical Hodgkin's lymphoma. Expert Opin. Ther. Targets 2010, 14, 577-584. [CrossRef]

271. Wang, Y.; Xiao, M.; Chen, X.; Chen, L.; Xu, Y.; Lv, L.; Wang, P.; Yang, H.; Ma, S.; Lin, H.; et al. WT1 recruits TET2 to regulate its target gene expression and suppress leukemia cell proliferation. Mol Cell 2015, 57, 662-673. [CrossRef]

272. Sinha, S.; Thomas, D.; Yu, L.; Gentles, A.J.; Jung, N.; Corces-Zimmerman, M.R.; Chan, S.M.; Reinisch, A.; Feinberg, A.P.; Dill, D.L.; et al. Mutant WT1 is associated with DNA hypermethylation of PRC2 targets in AML and responds to EZH2 inhibition. Blood 2015, 125, 316-326. [CrossRef] [PubMed]

273. Rampal, R.; Alkalin, A.; Madzo, J.; Vasanthakumar, A.; Pronier, E.; Patel, J.; Li, Y.; Ahn, J.; Abdel-Wahab, O.; Shih, A.; et al. DNA hydroxymethylation profiling reveals that WT1 mutations result in loss of TET2 function in acute myeloid leukemia. Cell Rep. 2014, 9, 1841-1855. [CrossRef] [PubMed]

274. Behm, F.G.; Raimondi, S.C.; Frestedt, J.L.; Liu, Q.; Crist, W.M.; Downing, J.R.; Rivera, G.K.; Kersey, J.H.; Pui, C.H. Rearrangement of the MLL gene confers a poor prognosis in childhood acute lymphoblastic leukemia, regardless of presenting age. Blood 1996, 87, 2870-2877. [CrossRef] [PubMed]

275. Shi, J.; Wang, E.; Zuber, J.; Rappaport, A.; Taylor, M.; Johns, C.; Lowe, S.W.; Vakoc, C.R. The Polycomb complex PRC2 supports aberrant self-renewal in a mouse model of MLL-AF9;Nras(G12D) acute myeloid leukemia. Oncogene 2013, 32, 930-938. [CrossRef]

276. Blackledge, N.P.; Farcas, A.M.; Kondo, T.; King, H.W.; McGouran, J.F.; Hanssen, L.L.P.; Ito, S.; Cooper, S.; Kondo, K.; Koseki, Y.; et al. Variant PRC1 complex-dependent H2A ubiquitylation drives PRC2 recruitment and polycomb domain formation. Cell 2014, 157, 1445-1459. [CrossRef]

277. Kalb, R.; Latwiel, S.; Baymaz, H.I.; Jansen, P.W.; Müller, C.W.; Vermeulen, M.; Müller, J. Histone H2A monoubiquitination promotes histone $\mathrm{H} 3$ methylation in Polycomb repression. Nat. Struct. Mol. Biol. 2014, 21, 569-571. [CrossRef]

278. Toyota, M.; Ahuja, N.; Ohe-Toyota, M.; Herman, J.G.; Baylin, S.B.; Issa, J.P. CpG island methylator phenotype in colorectal cancer. Proc. Natl. Acad. Sci. USA 1999, 96, 8681-8686. [CrossRef]

279. Zhang, M.T.; Huang, T.; Wang, R.F. Cross talk of chromosome instability, CpG island methylator phenotype and mismatch repair in colorectal cancer. Oncol. Lett. 2018, 16, 1736-1746. [CrossRef]

280. Weisenberger, D.J. Characterizing DNA methylation alterations from The Cancer Genome Atlas. J. Clin. Investig. 2014, 124, 17-23. [CrossRef]

281. Hon, G.C.; Hawkins, R.D.; Caballero, O.L.; Lo, C.; Lister, R.; Pelizzola, M.; Valsesia, A.; Ye, Z.; Kuan, S.; Edsall, L.E.; et al. Global DNA hypomethylation coupled to repressive chromatin domain formation and gene silencing in breast cancer. Genome Res. 2012, 22, 246-258. [CrossRef]

282. Parsons, D.W.; Jones, S.; Zhang, X.; Lin, J.C.-H.; Leary, R.J.; Angenendt, P.; Mankoo, P.; Carter, H.; Siu, I.M.; Gallia, G.L.; et al. An integrated genomic analysis of human glioblastoma multiforme. Science 2008, 321, 1807-1812. [CrossRef] [PubMed]

283. Noushmehr, H.; Weisenberger, D.J.; Diefes, K.; Phillips, H.S.; Pujara, K.; Berman, B.P.; Pan, F.; Pelloski, C.E.; Sulman, E.P.; Bhat, K.P.; et al. Identification of a CpG island methylator phenotype that defines a distinct subgroup of glioma. Cancer Cell 2010, 17, 10-522. [CrossRef] [PubMed] 
284. Verhaak, R.G.W.; Hoadley, K.A.; Purdom, E.; Wang, V.; Qi, Y.; Wilkerson, M.D.; Miller, C.R.; Ding, L.; Golub, T.; Mesirov, J.P.; et al. Integrated genomic analysis identifies clinically relevant subtypes of glioblastoma characterized by abnormalities in PDGFRA, IDH1, EGFR, and NF1. Cancer Cell 2010, 17, 98-110. [CrossRef]

285. Turcan, S.; Rohle, D.; Goenka, A.; Walsh, L.A.; Fang, F.; Yilmaz, E.; Fabius, A.W.M.; Lu, C.; Ward, P.S.; Thompson, C.B.; et al. IDH1 mutation is sufficient to establish the glioma hypermethylator phenotype. Nature 2012, 483, 479-483. [CrossRef] [PubMed]

286. Duncan, C.G.; Barwick, B.G.; Fau-Jin, G.; Jin, G.; Rago, C.; Kapoor-Vazirani, P.; Powell, D.R.; Chi, J.-T.; Bigner, D.D.; Vertino, P.M.; et al. A heterozygous IDH1R132H/WT mutation induces genome-wide alterations in DNA methylation. Nature 2012, 483, 479-483. [CrossRef]

287. Cohen, L.A.; Holmen, S.L.; Colman, H. IDH1 and IDH2 mutations in gliomas. Curr. Neurol. Neurosci. Rep. 2013, 13, 345. [CrossRef]

288. Dang, L.; White, D.W.; Gross, S.; Bennett, B.D.; Bittinger, M.A.; Driggers, E.M.; Fantin, V.R.; Jang, H.G.; Jin, S.; Keenan, M.C.; et al. Cancer-associated IDH1 mutations produce 2-hydroxyglutarate. Nature 2010, 465, 966. [CrossRef]

289. Jin, G.; Reitman, Z.J.; Duncan, C.G.; Spasojevic, I.; Gooden, D.M.; Rasheed, B.A.; Yang, R.; Lopez, G.Y.; He, Y.; McLendon, R.E.; et al. Disruption of wild-type IDH1 suppresses D-2-hydroxyglutarate production in IDH1-mutated gliomas. Cancer Res. 2013, 73, 496-501. [CrossRef]

290. Ward, P.S.; Patel, J.; Wise, D.R.; Abdel-Wahab, O.; Bennett, B.D.; Coller, H.A.; Cross, J.R.; Fantin, V.R.; Hedvat, C.V.; Perl, A.E.; et al. The common feature of leukemia-associated IDH1 and IDH2 mutations is a neomorphic enzyme activity converting alpha-ketoglutarate to 2-hydroxyglutarate. Cancer Cell 2010, 17, 225-234. [CrossRef]

291. Fujii, T.; Khawaja, M.R.; DiNardo, C.D.; Atkins, J.T.; Janku, F. Targeting isocitrate dehydrogenase (IDH) in cancer. Discov. Med. 2016, 21, 373-380.

292. Gross, S.; Cairns, R.A.; Minden, M.D.; Driggers, E.M.; Bittinger, M.A.; Jang, H.G.; Sasaki, M.; Jin, S.; Schenkein, D.P.; Su, S.M.; et al. Cancer-associated metabolite 2-hydroxyglutarate accumulates in acute myelogenous leukemia with isocitrate dehydrogenase 1 and 2 mutations. J. Exp. Med. 2010, 207, 339-344. [CrossRef] [PubMed]

293. Lu, C.; Ward, P.S.; Kapoor, G.S.; Rohle, D.; Turcan, S.; Abdel-Wahab, O.; Edwards, C.R.; Khanin, R.; Figueroa, M.E.; Melnick, A.; et al. IDH mutation impairs histone demethylation and results in a block to cell differentiation. Nature 2012, 483, 474-478. [CrossRef] [PubMed]

294. Chang, S.; Yim, S.; Park, H. The cancer driver genes IDH1/2, JARID1C/ KDM5C, and UTX/ KDM6A: Crosstalk between histone demethylation and hypoxic reprogramming in cancer metabolism. Exp. Mol. Med. 2019, 51, 1-17. [CrossRef] [PubMed]

295. Saygin, C.; Matei, D.; Majeti, R.; Reizes, O.; Lathia, J.D. Targeting Cancer Stemness in the Clinic: From Hype to Hope. Cell. Stem Cell 2019, 24, 25-40. [CrossRef]

296. Prager, B.C.; Xie, Q.; Bao, S.; Rich, J.N. Cancer Stem Cells: The Architects of the Tumor Ecosystem. Cell Stem Cell. 2019, 24, 41-53. [CrossRef]

297. Davis, L.R.; Weintraub, H.; Lassar, A.B. Expression of a single transfected cDNA converts fibroblasts to myoblasts. Cell 1987, 51, 987-1000. [CrossRef]

298. Takahashi, K.; Tanabe, K.; Ohnuki, M.; Narita, M.; Ichisaka, T.; Tomoda, K.; Yamanaka, S. Induction of pluripotent stem cells from adult human fibroblasts by defined factors. Cell 2007, 131, 861-872. [CrossRef]

299. Takahashi, K.; Yamanaka, S. Induction of pluripotent stem cells from mouse embryonic and adult fibroblast cultures by defined factors. Cell 2006, 126, 663-676. [CrossRef]

300. Vicente-Duenas, C.; Gutierrez de Diego, J.; Rodriguez, F.D.; Jimenez, R.; Cobaleda, C. The role of cellular plasticity in cancer development. Curr. Med. Chem. 2009, 16, 3676-3685. [CrossRef]

301. Aiello, N.M.; Maddipati, R.; Norgard, R.J.; Balli, D.; Li, J.; Yuan, S.; Yamazoe, T.; Black, T.; Sahmoud, A.; Furth, E.E.; et al. EMT Subtype Influences Epithelial Plasticity and Mode of Cell Migration. Dev. Cell 2018, 45, 681-695. [CrossRef] 
302. Poltavets, V.; Kochetkova, M.; Pitson, S.M.; Samuel, M.S. The Role of the Extracellular Matrix and Its Molecular and Cellular Regulators in Cancer Cell Plasticity. Front. Oncol. 2018, 8, 431. [CrossRef] [PubMed]

303. Leight, J.L.; Wozniak, M.A.; Chen, S.; Lynch, M.L.; Chen, C.S. Matrix rigidity regulates a switch between TGF- $\beta 1$-induced apoptosis and epithelial-mesenchymal transition. Mol. Biol. Cell 2012, 23, 781-791. [CrossRef] [PubMed]

304. Zhang, J.; Tian, X.J.; Xing, J. Signal Transduction Pathways of EMT Induced by TGF-beta, SHH, and WNT and Their Crosstalks. J. Clin. Med. 2016, 5, 41. [CrossRef] [PubMed]

305. Peinado, H.; Quintanilla, M.; Cano, A. Transforming growth factor beta-1 induces snail transcription factor in epithelial cell lines: Mechanisms for epithelial mesenchymal transitions. J. Biol. Chem. 2003, 278, 21113-21123. [CrossRef]

306. Yang, J.; Mani, S.A.; Donaher, J.L.; Ramaswamy, S.; Itzykson, R.A.; Come, C.; Savagner, P.; Gitelman, I.; Richardson, A.; Weinberg, R.A. Twist, a master regulator of morphogenesis, plays an essential role in tumor metastasis. Cell 2004, 117, 927-939. [CrossRef]

307. Batlle, E.; Sancho, E.; Francí, C.; Domínguez, D.; Monfar, M.; Baulida, J.; García De Herreros, A. The transcription factor snail is a repressor of E-cadherin gene expression in epithelial tumour cells. Nat. Cell Biol. 2000, 2, 84-89. [CrossRef]

308. Cano, A.; Pérez-Moreno, M.A.; Rodrigo, I.; Locascio, A.; Blanco, M.J.; del Barrio, M.G.; Portillo, F.; Nieto, M.A. The transcription factor snail controls epithelial-mesenchymal transitions by repressing E-cadherin expression. Nat. Cell Biol. 2000, 2, 76-83. [CrossRef]

309. Mani, S.A.; Yang, J.; Brooks, M.; Schwaninger, G.; Zhou, A.; Miura, N.; Kutok, J.L.; Hartwell, K.; Richardson, A.L.; Weinberg, R.A. Mesenchyme Forkhead 1 (FOXC2) plays a key role in metastasis and is associated with aggressive basal-like breast cancers. Proc. Natl. Acad. Sci. USA 2007, 104, 10069-10074. [CrossRef]

310. Gregory, P.A.; Bert, A.G.; Paterson, E.L.; Barry, S.C.; Tsykin, A.; Farshid, G.; Vadas, M.A.; Khew-Goodall, Y.; Goodall, G.J. The miR-200 family and miR-205 regulate epithelial to mesenchymal transition by targeting ZEB1 and SIP1. Nat. Cell Biol. 2008, 10, 593-601. [CrossRef]

311. Taube, J.H.; Malouf, G.G.; Lu, E.; Sphyris, N.; Vijay, V.; Ramachandran, P.P.; Ueno, K.R.; Gaur, S.; Nicoloso, M.S.; Rossi, S.; et al. Epigenetic silencing of microRNA-203 is required for EMT and cancer stem cell properties. Sci. Rep. 2013, 3, 2687. [CrossRef]

312. Korpal, M.; Lee, E.S.; Hu, G.; Kang, Y. The miR-200 family inhibits epithelial-mesenchymal transition and cancer cell migration by direct targeting of E-cadherin transcriptional repressors ZEB1 and ZEB2. J. Biol. Chem. 2008, 283, 14910-14914. [CrossRef] [PubMed]

313. Park, S.M.; Gaur, A.B.; Lengyel, E.; Peter, M.E. The miR-200 family determines the epithelial phenotype of cancer cells by targeting the E-cadherin repressors ZEB1 and ZEB2. Genes Dev. 2008, 22, 894-907. [CrossRef] [PubMed]

314. Sanchez-Tillo, E.; Lazaro, A.; Torrent, R.; Cuatrecasas, M.; Vaquero, E.C.; Castells, A.; Engel, P.; Postigo, A. ZEB1 represses E-cadherin and induces an EMT by recruiting the SWI/SNF chromatin-remodeling protein BRG1. Oncogene 2010, 29, 3490-3500. [CrossRef]

315. Jordan, N.V.; Prat, A.; Abell, A.N.; Zawistowski, J.S.; Sciaky, N.; Karginova, O.A.; Zhou, B.; Golitz, B.T.; Perou, C.M.; Johnson, G.L. SWI/SNF chromatin-remodeling factor Smarcd3/Baf60c controls epithelial-mesenchymal transition by inducing Wnt5a signaling. Mol. Cell Biol. 2013, 33, 3011-3025. [CrossRef] [PubMed]

316. Fu, J.; Qin, L.; He, T.; Qin, J.; Hong, J.; Wong, J.; Liao, L.; Xu, J. The TWIST/Mi2/NuRD protein complex and its essential role in cancer metastasis. Cell Res. 2011, 21, 275-289. [CrossRef] [PubMed]

317. Dong, C.; Wu, Y.; Yao, J.; Wang, Y.; Yu, Y.; Rychahou, P.G.; Evers, B.M.; Zhou, B.P. G9a interacts with Snail and is critical for Snail-mediated E-cadherin repression in human breast cancer. J. Clin. Investig. 2012, 122, 1469-1486. [CrossRef]

318. Mizuguchi, Y.; Specht, S.; Lunz, J.G., 3rd; Isse, K.; Corbitt, N.; Takizawa, T.; Demetris, A.J. Cooperation of p300 and PCAF in the control of microRNA 200c/141 transcription and epithelial characteristics. PLoS ONE 2012, 7, e32449. [CrossRef]

319. Aghdassi, A.; Sendler, M.; Guenther, A.; Mayerle, J.; Behn, C.O.; Heidecke, C.D.; Friess, H.; Buchler, M.; Evert, M.; Lerch, M.M.; et al. Recruitment of histone deacetylases HDAC1 and HDAC2 by the transcriptional repressor ZEB1 downregulates E-cadherin expression in pancreatic cancer. Gut 2012, 61, 439-448. [CrossRef] 
320. Cao, Q.; Yu, J.; Dhanasekaran, S.M.; Kim, J.H.; Mani, R.S.; Tomlins, S.A.; Mehra, R.; Laxman, B.; Cao, X.; $\mathrm{Yu}, \mathrm{J}$; ; et al. Repression of E-cadherin by the polycomb group protein EZH2 in cancer. Oncogene 2008, 27, 7274-7284. [CrossRef]

321. Herranz, N.; Pasini, D.; Díaz, V.M.; Francí, C.; Gutierrez, A.; Dave, N.; Escrivà, M.; Hernandez-Muñoz, I.; Di Croce, L.; Helin, K.; et al. Polycomb complex 2 is required for E-cadherin repression by the Snail1 transcription factor. Mol. Cell Biol. 2008, 28, 4772-4781. [CrossRef]

322. Iliopoulos, D.; Lindahl-Allen, M.; Polytarchou, C.; Hirsch, H.A.; Tsichlis, P.N.; Struhl, K. Loss of miR-200 inhibition of Suz12 leads to polycomb-mediated repression required for the formation and maintenance of cancer stem cells. Mol. Cell 2010, 39, 761-772. [CrossRef] [PubMed]

323. Xia, R.; Jin, F.Y.; Lu, K.; Wan, L.; Xie, M.; Xu, T.P.; De, W.; Wang, Z.X. SUZ12 promotes gastric cancer cell proliferation and metastasis by regulating KLF2 and E-cadherin. Tumour. Biol. 2015, 36, 5341-5351. [CrossRef] [PubMed]

324. Wright, M.H.; Calcagno, A.M.; Salcido, C.D.; Carlson, M.D.; Ambudkar, S.V.; Varticovski, L. Brca1 breast tumors contain distinct CD44+/CD24- and CD133+ cells with cancer stem cell characteristics. Breast Cancer Res. 2008, 10, R10. [CrossRef] [PubMed]

325. Collett, K.; Eide, G.E.; Arnes, J.; Stefansson, I.M.; Eide, J.; Braaten, A.; Aas, T.; Otte, A.P.; Akslen, L.A. Expression of enhancer of zeste homologue 2 is significantly associated with increased tumor cell proliferation and is a marker of aggressive breast cancer. Clin. Cancer Res. 2006, 12, 1168-1174. [CrossRef]

326. Kleer, C.G.; Cao, Q.; Varambally, S.; Shen, R.; Ota, I.; Tomlins, S.A.; Ghosh, D.; Sewalt, R.G.; Otte, A.P.; Hayes, D.F.; et al. EZH2 is a marker of aggressive breast cancer and promotes neoplastic transformation of breast epithelial cells. Proc. Natl. Acad. Sci. USA 2003, 100, 11606-11611. [CrossRef]

327. Puppe, J.; Drost, R.; Liu, X.; Joosse, S.A.; Evers, B.; Cornelissen-Steijger, P.; Nederlof, P.; Yu, Q.; Jonkers, J.; van Lohuizen, M.; et al. BRCA1-deficient mammary tumor cells are dependent on EZH2 expression and sensitive to Polycomb Repressive Complex 2-inhibitor 3-deazaneplanocin A. Breast Cancer Res. 2009, 11, R63. [CrossRef]

328. Song, L.B.; Li, J.; Liao, W.T.; Feng, Y.; Yu, C.P.; Hu, L.J.; Kong, Q.L.; Xu, L.H.; Zhang, X.; Liu, W.L.; et al. The polycomb group protein Bmi-1 represses the tumor suppressor PTEN and induces epithelial-mesenchymal transition in human nasopharyngeal epithelial cells. J. Clin. Investig. 2009, 119, 3626-3636. [CrossRef]

329. Martin, A.; Cano, A. Tumorigenesis: Twist1 links EMT to self-renewal. Nat. Cell Biol. 2010, 12, $924-925$. [CrossRef]

330. Yang, M.H.; Hsu, D.S.; Wang, H.W.; Wang, H.J.; Lan, H.Y.; Yang, W.H.; Huang, C.H.; Kao, S.Y.; Tzeng, C.H.; Tai, S.K.; et al. Bmi1 is essential in Twist1-induced epithelial-mesenchymal transition. Nat. Cell Biol. 2010, 12, 982-992. [CrossRef]

331. Chaffer, C.L.; Marjanovic, N.D.; Lee, T.; Bell, G.; Kleer, C.G.; Reinhardt, F.; D’Alessio, A.C.; Young, R.A.; Weinberg, R.A. Poised chromatin at the ZEB1 promoter enables breast cancer cell plasticity and enhances tumorigenicity. Cell 2013, 154, 61-74. [CrossRef]

332. Dhar, S.S.; Lee, S.H.; Chen, K.; Zhu, G.; Oh, W.; Allton, K.; Gafni, O.; Kim, Y.Z.; Tomoiga, A.S.; Barton, M.C.; et al. An essential role for UTX in resolution and activation of bivalent promoters. Nucleic Acids Res. 2016, 44, 3659-3674. [CrossRef] [PubMed]

333. Ramadoss, S.; Chen, X.; Wang, C.Y. Histone demethylase KDM6B promotes epithelial-mesenchymal transition. J. Biol. Chem. 2012, 287, 44508-44517. [CrossRef] [PubMed]

334. Serresi, M.; Gargiulo, G.; Proost, N.; Siteur, B.; Cesaroni, M.; Koppens, M.; Xie, H.; Sutherland, K.D.; Hulsman, D.; Citterio, E.; et al. Polycomb Repressive Complex 2 Is a Barrier to KRAS-Driven Inflammation and Epithelial-Mesenchymal Transition in Non-Small-Cell Lung Cancer. Cancer Cell 2016, 29, 17-31. [CrossRef]

335. Markopoulos, G.S.; Roupakia, E.; Marcu, K.B.; Kolettas, E. Epigenetic Regulation of Inflammatory Cytokine-Induced Epithelial-To-Mesenchymal Cell Transition and Cancer Stem Cell Generation. Cells 2019, 8, 1143. [CrossRef] [PubMed]

336. Peixoto, P.; Etcheverry, A.; Aubry, M.; Missey, A.; Lachat, C.; Perrard, J.; Hendrick, E.; Delage-Mourroux, R.; Mosser, J.; Borg, C.; et al. EMT is associated with an epigenetic signature of ECM remodeling genes. Cell Death Dis. 2019, 10, 205. [CrossRef]

337. Zha, L.; Cao, Q.; Cui, X.; Li, F.; Liang, H.; Xue, B.; Shi, H. Epigenetic regulation of E-cadherin expression by the histone demethylase UTX in colon cancer cells. Med. Oncol. 2016, 33, 21. [CrossRef] [PubMed] 
338. Choi, H.J.; Park, J.H.; Park, M.; Won, H.Y.; Joo, H.S.; Lee, C.H.; Lee, J.Y.; Kong, G. UTX inhibits EMT-induced breast CSC properties by epigenetic repression of EMT genes in cooperation with LSD1 and HDAC1. EMBO Rep. 2015, 16, 1288-1298. [CrossRef] [PubMed]

339. Taube, J.H.; Sphyris, N.; Johnson, K.S.; Reisenauer, K.N.; Nesbit, T.A.; Joseph, R.; Vijay, G.V.; Sarkar, T.R.; Bhangre, N.A.; Song, J.J.; et al. The H3K27me3-demethylase KDM6A is suppressed in breast cancer stem-like cells, and enables the resolution of bivalency during the mesenchymal-epithelial transition. Oncotarget 2017, 8, 65548-65565. [CrossRef] [PubMed]

340. Yan, N.; Xu, L.; Wu, X.; Zhang, L.; Fei, X.; Cao, Y.; Zhang, F. GSKJ4, an H3K27me3 demethylase inhibitor, effectively suppresses the breast cancer stem cells. Exp. Cell Res. 2017, 359, 405-414. [CrossRef]

341. Terashima, M.; Ishimura, A.; Wanna-Udom, S.; Suzuki, T. Epigenetic regulation of epithelial-mesenchymal transition by KDM6A histone demethylase in lung cancer cells. Biochem Biophys.. Res. Commun. 2017, 490, 1407-1413. [CrossRef]

342. van den Beucken, T.; Koch, E.; Chu, K.; Rupaimoole, R.; Prickaerts, P.; Adriaens, M.; Voncken, J.W.; Harris, A.L.; Buffa, F.M.; Haider, S.; et al. Hypoxia promotes stem cell phenotypes and poor prognosis through epigenetic regulation of DICER. Nat. Commun. 2014, 5, 5203. [CrossRef] [PubMed]

343. Benedetti, R.; Dell'Aversana, C.; De Marchi, T.; Rotili, D.; Liu, N.Q.; Novakovic, B.; Boccella, S.; Di Maro, S.; Cosconati, S.; Baldi, A.; et al. Inhibition of Histone Demethylases LSD1 and UTX Regulates ERalpha Signaling in Breast Cancer. Cancers (Basel) 2019, 11, 2027. [CrossRef] [PubMed]

344. Liau, B.B.; Sievers, C.; Donohue, L.K.; Gillespie, S.M.; Flavahan, W.A.; Miller, T.E.; Venteicher, A.S.; Hebert, C.H.; Carey, C.D.; Rodig, S.J.; et al. Adaptive Chromatin Remodeling Drives Glioblastoma Stem Cell Plasticity and Drug Tolerance. Cell Stem Cell 2017, 20, 233-246. [CrossRef] [PubMed]

345. Kong, D.; Hughes, C.J.; Ford, H.L. Cellular Plasticity in Breast Cancer Progression and Therapy. Front. Mol. Biosci. 2020, 7, 72. [CrossRef]

346. Bradner, J.E.; Hnisz, D.; Young, R.A. Transcriptional Addiction in Cancer. Cell 2017, 168, 629-643. [CrossRef]

347. Dekker, J.; Misteli, T. Long-Range Chromatin Interactions. Cold Spring Harb. Perspect. Biol. 2015, 7, a019356. [CrossRef]

348. Dixon, J.R.; Gorkin, D.U.; Ren, B. Chromatin Domains: The Unit of Chromosome Organization. Mol. Cell. 2016, 62, 668-680. [CrossRef]

349. Allis, D.C.; Jenuwein, T. The molecular hallmarks of epigenetic control. Nat. Rev. Genet. 2016, 17, 487-500. [CrossRef]

350. Margueron, R.; Reinberg, D. Chromatin structure and the inheritance of epigenetic information. Nat. Rev. Genet. 2010, 11, 285-296. [CrossRef]

351. Waddington, C.H. The Strategy of the Genes; Routledge: London, UK, 2014.

352. Brock, A.; Chang, H.; Huang, S. Non-genetic heterogeneity-a mutation-independent driving force for the somatic evolution of tumours. Nat. Rev. Genet. 2009, 10, 336-342. [CrossRef]

353. Morera, L.; Lübbert, M.; Jung, M. Targeting histone methyltransferases and demethylases in clinical trials for cancer therapy. Clin. Epigenet. 2016, 8, 57. [CrossRef] [PubMed]

354. Hashizume, R.; Andor, N.; Ihara, Y.; Lerner, R.; Gan, H.; Chen, X.; Fang, D.; Huang, X.; Tom, M.W.; Ngo, V.; et al. Pharmacologic inhibition of histone demethylation as a therapy for pediatric brainstem glioma. Nat. Med. 2014, 20, 1394-1396. [CrossRef] [PubMed]

(C) 2020 by the authors. Licensee MDPI, Basel, Switzerland. This article is an open access article distributed under the terms and conditions of the Creative Commons Attribution (CC BY) license (http://creativecommons.org/licenses/by/4.0/). 